Article

\title{
The Causality between Participation in GVCs, Renewable Energy Consumption and $\mathrm{CO}_{2}$ Emissions
}

\author{
Zhiheng Wu, Guisheng Hou ${ }^{(D)}$ and Baogui Xin * \\ College of Economics and Management, Shandong University of Science and Technology, Qingdao 266590, \\ China; zhihengwu16@sdust.edu.cn (Z.W.); houguisheng001@sdust.edu.cn (G.H.) \\ * Correspondence: xin@tju.edu.cn; Tel.: +86-532-8605-7025
}

Received: 10 December 2019; Accepted: 6 February 2020; Published: 8 February 2020

\begin{abstract}
Using the panel vector autoregressive (PVAR) model accompanied by the system-generalized method of moment (System-GMM) approach, this paper investigates the dynamic causality between participation in global value chains (GVCs), renewable energy consumption and carbon dioxide $\left(\mathrm{CO}_{2}\right)$ emissions throughout 1990-2015 for 172 countries. The results show that participation in GVCs negatively causes renewable energy consumption except for the Middle East and North America (MENA) and sub-Saharan Africa. Second, except for the Asia-Pacific region and globally, participation in GVCs has no causal impact on $\mathrm{CO}_{2}$ emissions, and participation in GVCs has a positive effect on $\mathrm{CO}_{2}$ emissions in the Asia-Pacific region and globally. Third, except for globally and sub-Saharan Africa, $\mathrm{CO}_{2}$ emissions have no causal impact on participation in GVCs; however, $\mathrm{CO}_{2}$ emissions hurt participation in GVCs globally and in the sub-Saharan African region. Forth, renewable energy consumption positively causes participation in GVCs in MENA, while renewable energy consumption does not cause participation in GVCs globally and in other regions. Fifth, there is no causality between $\mathrm{CO}_{2}$ emissions and renewable energy consumption both at the global and regional levels. Several policy implications are proposed and discussed for promoting participation in GVCs and improving the environment.
\end{abstract}

Keywords: participation; GVCs; renewable energy consumption; $\mathrm{CO}_{2}$ emissions; PVAR

\section{Introduction}

Global climate warming and energy scarcity are consensually regarded as the most challenging and threatening global environmental issues, which will severely affect all aspects of human life and health [1-4]. To ensure the energy security and sustainable development of human society, the relevant international organizations, policymakers and researchers have highlighted the significance of governing global warming and reducing greenhouse gas (GHG) emissions. In particular, as production sharing becomes the significant characteristic of today's global economy [5], much debate about the environmental consequences of participation in global value chains (GVCs) has emerged [6]. According to the recent report of the United Nations' Sustainable Development Goals, "Global supply chains play a critical role in many of the most pressing environmental stresses and social struggles" [7], which clearly emphasizes the effect of GVCs on the environment.

As carbon dioxide $\left(\mathrm{CO}_{2}\right)$ emissions are the primary source of climate warming, mitigating $\mathrm{CO}_{2}$ emissions is the key to solving the problem of global climate change [8-11]. There is strong agreement among researchers that renewable energy provides a promising solution to stimulate $\mathrm{CO}_{2}$ emission reduction [12,13]. Widespread use of renewable energy and further technological advancement of renewable energy technologies are all conducive to decreasing $\mathrm{CO}_{2}$ emissions [14,15]. At the same time, it is widely accepted that integration in GVCs plays a growing role in accessing knowledge and enhancing learning and innovation ability [16], which is vital to the development of eco-technology 
and the use of renewable energy. However, participation in GVCs might increase $\mathrm{CO}_{2}$ emissions in turn [17]. These contradictory views make it a challenge for policymakers to make reasonable and consistent industrial development policies aiming at increasing the share of participation in GVCs while concurrently protecting the environment and saving energy.

Two parallel literatures on the relationship between participation in GVCs and the environment have emerged. The first group of studies shows that participation in GVCs is environmentally beneficial [18-20]. The increase of participation in GVCs can prevent environmental deterioration and save energy due to several channels. First, technology spillovers and labor transfer through participation in GVCs contribute to the transfer of environmental technology and new energy technology [6,21-24]. Second, participation in GVCs contributes to the process of technology diffusion and the sharing of technical information, reducing the emissions and increasing the use of renewable energy use [25-28]. Besides, participation in GVCs also means that the firms face differentiated and co-evolving environmental constraints and standards $[29,30]$. Supplier firms must comply with global standards and environmental certifications, which can cut down their carbon footprints, to avoid being excluded from GVCs [31-34]. Furthermore, participation in GVCs can lead to less raw material consumption and waste by extending product life [35,36].

While some scholars have claimed that participation in GVCs leads to environmental degradation [37], the increase in participation in GVCs can increase energy consumption and $\mathrm{CO}_{2}$ emissions due to several channels. First, participation in GVCs is associated with greater distance between nodes in the distribution network, and greater distances translate into higher $\mathrm{CO}_{2}$ emissions of lorries [38,39]. The emergence and expansion of GVCs have increased the importance of logistics and transport (including maritime shipping) [40,41], which are regarded as significant emitters of air pollutants [42]. Second, participation in global value chains further accelerates the growth of the global energy footprint, in which stronger backward linkages can increase the energy use [43]. Third, international carbon leakage and $\mathrm{CO}_{2}$ emissions traded internationally through GVCs lead to emissions burden-shifting and threaten mitigation targets [44-46].

However, with the extensive literature on the impacts of participation in GVCs on renewable energy consumption and $\mathrm{CO}_{2}$ emissions, few studies have been done on the causal relationship among participation in GVCs, renewable energy consumption and $\mathrm{CO}_{2}$ emissions. In addition, only a few studies have simultaneously focused on renewable energy consumption and $\mathrm{CO}_{2}$ emissions to verify the relationship between them and participation in GVCs. This paper, therefore, aims to fill these gaps by employing a multivariate panel approach, which also includes variables of economic growth and labor force, since economic growth and labor force have significant impacts on these variables.

As fewer empirical results have addressed the issue of the causality between participation in GVCs, renewable energy consumption and $\mathrm{CO}_{2}$ emissions, we contribute to the literature in three ways. First, we employ the panel vector auto-regression (PVAR) to fill the gap in the empirical literature by examining the causality between participation in GVCs, renewable energy consumption and $\mathrm{CO}_{2}$ emissions from the global and region levels. Second, to best of our knowledge, this is the first study that applies large samples of 172 countries over the period of 1995-2015 to explore the causality of participation in GVCs, renewable energy consumption and $\mathrm{CO}_{2}$ emissions. Finally, we put forward several sound policy recommendations designed to improve the environment while enhancing participation in GVCs.

The remainder of the paper is organized in the following manner: Section 2 reviews the literature and is followed by Section 3, which describes the methodology and data. Section 4 introduces the empirical results and provides discussions. Section 5 concludes the main results and puts forward the policy implications in terms of global and regional levels. 


\section{Literature Review}

This section mainly reviews the literatures that have measured the participation in GVCs and examined the relationship among participation in GVCs, energy consumption and $\mathrm{CO}_{2}$ emissions, as well as the causality between $\mathrm{CO}_{2}$ emissions and renewable energy consumption.

\subsection{Measurement of Participation in GVCs}

From the perspective of international production networks, Gereffi $[47,48]$ initially defined GVCs as the configuration of coordinated activities, which contain design, production, marketing, transport, retail and disposal or recycling that are "divided among firms and that have a global geographical scale". As GVCs become the new trend of global production division, many literatures have put forward methods to measure the participation in GVCs. Hummels et al. [49] proposed the concept of "Vertical specialization" (VS), which was defined as the use of imported intermediate goods in producing goods that are exported, indicating that fragmentation, outsourcing and slicing the value chain cause the vertical trading chain to stretch across countries. They then developed the HIY (Hummels, Ishii and Yi) method, which uses the ratio of imported input content of exports to measure the VS. It is understood that the HIY method has some shortcomings, which turn out to be accurate only under two special assumptions that do not hold in general. First, the intensity of the use of imported intermediates inputs is assumed to be the same whether production is for export or production is for domestic final consumption. Second, imported inputs for production should be $100 \%$ foreign sourced. Liu et al. [37] claims that the HIY method fails to capture all value-added sources in gross exports in multi-country production networks. For overcoming these limitations, Daudin et al. [50] and Johnson and Noguera [51] improved the HIY method from the value-added trade perspective. Daudin et al. [50] defined value-added trade as the standard trade minus vertical trade and put forward the method for measuring part of VS1, which refers to the value of a country's exports that are used as imported intermediate inputs by other countries of the world to produce exports back to home. Johnson and Noguera [51] defined value-added exports as value-added produced in the country of origin and absorbed in another destination country and proposed value-added to gross export ratio (VAX ratio) for measuring the intensity of production sharing. However, these two methods are more closely related to the factor content discussions in the trade instead of HIY's original concepts [52]. Koopman et al. [53,54] provided the KPWW (Koopman, Powers, Wang and Wei) method to measure country's participation in global production chains by completely decomposing gross exports into various value-added components by source, containing exports of value added, domestic gross exports that return home, foreign value added and other additional double counted terms. The KPWW technique provides an accounting formula quantifying all kinds of double counted items and establishes a precise relationship between value-added measures of trade and official trade statistics, which allow us to gauge the depth and the pattern of one country's participation in GVCs. Moreover, relying on the literature of the KPWW method, some recent studies computed the participation in GVCs by calculating the indirect domestic value added (DVX) share and foreign value added (FVA) share of total exports [55-58].

\subsection{Impacts of Participation in GVCs on Environment and Energy Consumption}

Participation in GVCs has a variety of impacts on energy consumption and $\mathrm{CO}_{2}$ emissions. Chiou et al. [59] concluded that working closely with supply chain partners promotes environmentally friendly product innovations, thereby creating advantages (e.g., better product quality) over rivals. Khattak et al. [19] considered that GVCs represent both the drivers of environmental upgrading and the means by which to obtain the knowledge needed to upgrade, particularly for firms in relational networks. Khattak and Stringer [31] examined the impact of GVCs on the environment and claimed that through regular interaction, knowledge is created and transferred across the GVCs, resulting in environmental upgrading. Pathikonda and Farole [60] suggested that GVCs have altered the nature of 
global trade, and offer significant opportunities for developing countries to expand exports, access technology and raise productivity.

However, not all impacts of participation in GVCs are equally helpful for energy conservation and environmental protection. Davis and Caldeira [46] pointed out that consumption-based accounting of $\mathrm{CO}_{2}$ emissions demonstrates the potential for international carbon leakage, and $\mathrm{CO}_{2}$ emissions traded internationally primarily export from China and other emerging markets to consumers in developed countries. Besides, Spaiser et al. [44] and Meng et al. [61] all considered that most developing countries, such as China, join GVCs by exporting relatively large amounts of final products in their early stage of development, which produce a large amount of $\mathrm{CO}_{2}$ emissions, which makes the poorer countries bear the natural depletion costs.

\subsection{Relationship between $\mathrm{CO}_{2}$ Emissions and Renewable Energy}

A wealth of empirical studies has emerged examining the possible causality between $\mathrm{CO}_{2}$ emissions and renewable energy, mainly divided into two categories, namely single country analysis and cross-country analysis. Findings of both categories have been mixed. More details about relevant studies are shown in Table 1. Since in this paper we examined the case of countries at global and regional levels, previous research with cross-country data is discussed in detail below. A majority of studies have found evidence for a bidirectional causal relationship between $\mathrm{CO}_{2}$ emissions and renewable energy (see Salim and Rafiq [62] for six emerging countries, Liu et al. [63] for ASEAN-4 countries, Jebli et al. [64] for 25 OECD countries, Dogan and Seker [65] for 15 EU countries and Dong et al. [66,67] for BRICS countries and 14 Asia-Pacific countries). Some previous studies have shown evidence for a unidirectional causal relationship between $\mathrm{CO}_{2}$ emissions and renewable energy, such as Al-mulali and Ozturk [68], who examined this for 27 advanced economies, and Balsalobre-Lorente et al. [69], who studied this for 5 EU countries. Furthermore, Bölük and Mert [70], Zoundi [71] and Bhattacharya et al. [72] demonstrates that renewable energy consumption has a significant negative effect on $\mathrm{CO}_{2}$ emissions, and renewable energy consumption is an efficient tool for protecting the environment.

Table 1. Summary of studies on the relationship between renewable energy (RE) and $\mathrm{CO}_{2}$ emissions.

\begin{tabular}{|c|c|c|c|c|}
\hline Author(s) & Country(ies) & Period & Methodology & Results \\
\hline $\begin{array}{c}\text { Menyah and } \\
\text { Wolde-Rufael [73] }\end{array}$ & US & $1960-2007$ & Granger causality test & $\begin{array}{l}\text { There is no causality running } \\
\text { from RE to } \mathrm{CO}_{2} \text { emissions. }\end{array}$ \\
\hline Pata [74] & Turkey & 1974-2014 & ARDL/FMOLS/CCR & $\begin{array}{l}\mathrm{RE} \text { has no effect on } \mathrm{CO}_{2} \\
\text { emissions. }\end{array}$ \\
\hline Dong et al. [75] & China & $1995-2014$ & Panel FMOLS/DOLS & $\begin{array}{l}\text { Natural gas consumption } \rightarrow \mathrm{CO}_{2} \\
\text { Natural gas consumption has a } \\
\text { significant negative impact on } \\
\mathrm{CO}_{2} \text { emissions }\end{array}$ \\
\hline $\begin{array}{l}\text { Ben Jebli and Ben } \\
\text { Youssef [76] }\end{array}$ & Tunisia & 1980-2009 & $\begin{array}{l}\text { ARDL/VECM Granger } \\
\text { causality approach }\end{array}$ & $\begin{array}{l}\mathrm{CO}_{2} \rightarrow \mathrm{RE} \text { (short run) } \\
\text { In the long-run, } \mathrm{RE} \text { impacts } \\
\text { weakly and negatively } \mathrm{CO}_{2} \\
\text { emissions when using the model } \\
\text { with exports, and this impact is } \\
\text { statistically insignificant when } \\
\text { using the model with imports. }\end{array}$ \\
\hline Dong et al. [77] & China & $1993-2016$ & $\begin{array}{l}\text { ARDL/VECM Granger } \\
\text { causality test }\end{array}$ & $\begin{array}{l}\text { In both the short and long run, } \\
\text { nuclear energy and renewable } \\
\text { energy play important roles in } \\
\text { mitigating } \mathrm{CO}_{2} \text { emissions }\end{array}$ \\
\hline $\begin{array}{c}\text { Sinha and Shahbaz } \\
\text { [78] }\end{array}$ & India & $1971-2015$ & ARDL & $\begin{array}{l}\mathrm{RE} \text { was found to have } \\
\text { significant negative impacts on } \\
\mathrm{CO}_{2} \text { emissions }\end{array}$ \\
\hline
\end{tabular}


Table 1. Cont.

\begin{tabular}{|c|c|c|c|c|}
\hline Author(s) & Country(ies) & Period & Methodology & Results \\
\hline $\begin{array}{l}\text { Salim and Rafiq } \\
\text { [62] }\end{array}$ & $\begin{array}{l}\text { Brazil, China, } \\
\text { Philippines, } \\
\text { India, Turkey, } \\
\text { Indonesia }\end{array}$ & 1980-2006 & $\begin{array}{l}\text { FMOLS/DOLS/Granger } \\
\text { causality methods }\end{array}$ & $\begin{array}{l}\mathrm{RE} \leftrightarrow \text { income; (short run) } \\
\mathrm{RE} \leftrightarrow \text { pollutant emission (short } \\
\text { run) }\end{array}$ \\
\hline $\begin{array}{l}\text { Balsalobre-Lorente } \\
\text { et al. [69] }\end{array}$ & EU-5 countries & $1985-2016$ & EKC model & $\begin{array}{l}\text { Renewable electricity } \\
\text { consumption } \rightarrow \mathrm{CO}_{2} \\
\text { Renewable electricity } \\
\text { consumption improves } \\
\text { environmental quality. }\end{array}$ \\
\hline $\begin{array}{l}\text { Bölük and Mert } \\
{[\text { [70] }}\end{array}$ & 16 EU countries & $1990-2008$ & $\begin{array}{l}\text { Panel fixed effect } \\
\text { model }\end{array}$ & $\begin{array}{l}\text { RE contributes around } 1 / 2 \text { less } \\
\text { per unit of energy consumed } \\
\text { than fossil energy consumption } \\
\text { in terms of GHG emissions in } \\
\text { EU countries. }\end{array}$ \\
\hline Dong et al. [66] & $\begin{array}{l}\text { BRICS } \\
\text { countries } \\
\text { ASEAN-4 }\end{array}$ & 1985-2016 & $\begin{array}{l}\text { VECM panel Granger } \\
\text { causality tests }\end{array}$ & $\begin{array}{l}\text { Gas consumption } \leftrightarrow \mathrm{CO}_{2} \\
\mathrm{RE} \leftrightarrow \mathrm{CO}_{2}\end{array}$ \\
\hline Liu et al. [63] & $\begin{array}{l}\text { countries } \\
\text { (Malaysia, } \\
\text { Thailand } \\
\text { Indonesia, } \\
\text { Philippines,) }\end{array}$ & $1970-2013$ & $\begin{array}{l}\text { Panel OLS/FMOLS/ } \\
\text { DOLS/ VECM Granger } \\
\text { causality test }\end{array}$ & $\begin{array}{l}\mathrm{RE} \leftrightarrow \mathrm{CO}_{2} \text { (long run) } \\
\text { The increasing RE decreases } \\
\mathrm{CO}_{2} \text { emissions. }\end{array}$ \\
\hline $\begin{array}{l}\text { Al-mulali and } \\
\text { Ozturk [68] }\end{array}$ & $\begin{array}{l}27 \text { advanced } \\
\text { economies }\end{array}$ & 1990-2012 & $\begin{array}{l}\text { Panel FMOLS/ } \\
\text { VEC granger } \\
\text { causality }\end{array}$ & $\begin{array}{l}\mathrm{RE} \rightarrow \mathrm{CO}_{2} \\
\text { Renewable energy can reduce } \\
\text { the } \mathrm{CO}_{2} \text { emissions. }\end{array}$ \\
\hline Dong et al. [77] & $\begin{array}{l}14 \text { Asia-Pacific } \\
\text { countries }\end{array}$ & 1970-2016 & $\begin{array}{l}\text { Panel FMOLS/ } \\
\text { Panel VECM } \\
\text { Granger causality } \\
\text { method }\end{array}$ & $\begin{array}{l}\text { Natural gas consumption } \leftrightarrow \\
\mathrm{CO}_{2} \text { (short run and long run) } \\
\text { Natural gas consumption has a } \\
\text { significantly negative effect on } \\
\mathrm{CO}_{2} \text { emissions. }\end{array}$ \\
\hline Zoundi [71] & $\begin{array}{l}25 \text { African } \\
\text { countries }\end{array}$ & $1980-2012$ & DOLS/FMOLS & $\begin{array}{l}\text { Renewable energy has a } \\
\text { negative effect on } \mathrm{CO}_{2} \\
\text { emissions, coupled with an } \\
\text { increasing long run effect. }\end{array}$ \\
\hline $\begin{array}{c}\text { Dogan and Seker } \\
{[65]}\end{array}$ & EU-15 countries & 1980-2012 & DOLS & $\begin{array}{l}\mathrm{RE} \leftrightarrow \mathrm{CO}_{2} \\
\mathrm{RE} \text { mitigates the } \mathrm{CO}_{2} \text { emissions. }\end{array}$ \\
\hline $\begin{array}{l}\text { Bhattacharya et al. } \\
\text { [72] }\end{array}$ & $\begin{array}{l}85 \text { developing } \\
\text { and developed } \\
\text { countries }\end{array}$ & $1992-2012$ & System-GMM/FMOLS & $\begin{array}{l}\text { Growth of RE has a significant } \\
\text { negative impact on } \mathrm{CO}_{2} \\
\text { emissions. }\end{array}$ \\
\hline Jebli et al. [64] & $\begin{array}{l}\text { OECD-25 } \\
\text { countries }\end{array}$ & 1980-2010 & FMOLS/DOLS & $\begin{array}{l}\mathrm{RE} \leftrightarrow \mathrm{CO}_{2} \text { (long run) } \\
\mathrm{RE} \text { reduces } \mathrm{CO}_{2} \text { emissions. }\end{array}$ \\
\hline
\end{tabular}

Notes: ARDL (Autoregressive distributed lagged); FMOLS (Fully modified ordinary least square); CCR (Canonical cointegrating regression); DOLS (Dynamic ordinary least square); VECM (Vector Error-Correction Model); EKC (Environmental Kuznets curve); OLS (Ordinary least square); System-GMM (System generalized method of moments)

\section{Methodology and Data}

\subsection{Methodology}

In order to comprehensively analyze the endogenous dependent relationship between participation in GVCs, renewable energy consumption and $\mathrm{CO}_{2}$ emissions, the PVAR model proposed by Love and Zicchino [79] was adopted in this paper. As a powerful analysis tool of macroeconomic dynamics, the PVAR model treats all the variables as endogenous and interdependent and allows for the existence of unobserved individual heterogeneity. The PVAR model is given as

$$
Y_{i, t}=\mu_{i}+\phi(I) Y_{i, t}+\alpha_{i}+\delta_{t}+\varepsilon_{i, t}
$$

where $Y_{i, t}$ is the vector of endogenous variables, and $\mu_{i}$ refers to the matrix of country-specific fixed effects; $i=1,2, \cdots N$ and $t=1,2, \cdots T$ represent the country and time, respectively. $\phi(I)$ is the lag 
operator of the matrix polynomial, $\alpha_{i}$ is the individual specific effects, $\delta_{t}$ is the time effects and $\varepsilon_{i, t}$ is the random error vector.

Based on the selection criteria of AIC (Akaike information criterion), HQIC (Hannan-Quinn information criterion) and BIC (Bayesian information criterion), the optimal lag of this model was confirmed as the first-order PVAR model. Therefore, Equation (1) can also be rewritten as

$$
\begin{aligned}
& d \operatorname{lng} d p_{i t}=\begin{array}{c}
\mu_{1 i}+a_{11} d \operatorname{lng} d p_{i t-1}+a_{12} \text { dlngvcs }_{i t-1}+a_{13} \text { dlnrec }_{i t-1}+ \\
a_{14} d_{\text {lnco }}{ }_{2 i t-1}+a_{15} \text { dlnlabor }_{i t-1}+\alpha_{1 t}+\delta_{1 t}+\varepsilon_{1 i t}
\end{array}, \\
& \operatorname{dlngvcs}_{i t}=\begin{array}{c}
\mu_{2 i}+a_{21} d \operatorname{lng} d p_{i t-1}+a_{22} \text { dlngvcs }_{i t-1}+a_{23} \text { dlnrec }_{i t-1}+ \\
a_{24} \text { dlnco }_{2} \text { lt }-1+a_{25} \text { dlnlabor }_{i t-1}+\alpha_{2 t}+\delta_{2 t}+\varepsilon_{2 i t}
\end{array}, \\
& \text { dlnec }_{i t}=\begin{array}{c}
\mu_{3 i}+a_{31} d \operatorname{lng} d p_{i t-1}+a_{32} \text { dlngves }_{i t-1}+a_{33} \text { dlnrec }_{i t-1}+ \\
a_{34} \text { dlnco }_{2}{ }_{i t-1}+a_{35} \text { dlnlabor }_{i t-1}+\alpha_{3 t}+\delta_{3 t}+\varepsilon_{3 i t}
\end{array}, \\
& \operatorname{dlnco}_{2} \text { it }=\begin{array}{c}
\mu_{4 i}+a_{41} d \operatorname{dng} d p_{i t-1}+a_{42} \text { dlngvcs }_{i t-1}+a_{43} \text { dlnrec }_{i t-1}+ \\
a_{44} \text { dlnco }_{2} \text { it-1 }+a_{45} \text { dlnlabor }_{i t-1}+\alpha_{4 t}+\delta_{4 t}+\varepsilon_{4 i t}
\end{array}, \\
& \text { dlncap }_{2}{ }_{i t}=\begin{array}{c}
\mu_{5 i}+a_{51} d \operatorname{lng} g p_{i t-1}+a_{52} \text { dlngvcs }_{i t-1}+a_{53} \text { dlnrec }_{i t-1}+ \\
a_{54} \text { dlnco }_{2}+a_{\text {it }-1}+a_{55} \text { dlnlabor }_{i t-1}+\alpha_{5 t}+\delta_{5 t}+\varepsilon_{5 i t}
\end{array} .
\end{aligned}
$$

During the process of estimation of the PVAR model, to eliminate the individual specific effect and fixed time effect, the mean-difference method and forward mean-difference (known as "Helmert procedure") method were applied. Then, the lagged independent variables were used as the tool variables to estimate the parameters of the model using the system-generalized method of moment.

\subsection{Data Selection and Description}

Annual data over the period of 1990-2015 for a total of 172 countries (see Appendix A for the countries used in this study) comes from the World Bank Development Indicators databases (WDI) and Euro database $[56,80]$. Economic growth was proxied using per capita GDP in current US dollars. Renewable energy consumption was represented by the percentage of renewable energy consumption of the total final energy consumption. $\mathrm{CO}_{2}$ emissions were measured by carbon dioxide emissions $(\mathrm{kg})$ per PPP (purchasing-power-parity) US dollars as a percent of GDP. The percentage of total labor force participation on total population ages 15-64 was used as a proxy for labor force. There are no direct statistics data on the participation in GVCs for all of the countries; thus, the relevant data was obtained by the formula as follows:

$$
\text { GVC Paticipation }_{i t}=\frac{F V A_{i t}+D V X_{i t}}{\text { Total Exports }}
$$

where $F V A_{i t}$ is the foreign value added, and $D V X_{i t}$ is the indirect domestic value added in country $i$ at time $t$. FVA share identifies the share of a country's exports, which consists of inputs produced in other countries, and it captures the extent of GVC participation for downstream firms and industries. It is considered a measure of backward GVC participation. DVX share captures the contribution of the domestic sector of a country to the exports of other countries, thus indicating the extent of GVC participation for relatively upstream sectors. It is considered as a measure of forward GVC participation. The FVA and the DVX components of a single country/area gives us a comprehensive description of GVC participation [57,58,81]. Total exports is measured by the exports of goods and services (BOP) in current US dollars. The larger the ratio, the greater the intensity of involvement of a particular country in GVCs. All the variables in this paper were converted to natural logarithm to eliminate heteroscedasticity and increase the reliability and consistency of the results. 


\section{Empirical Results and Discussion}

This section discusses the main results of the estimation of the system-generalized method of moment (System-GMM) PVAR model and presents the results of variance decomposition and impulse response function analysis.

\subsection{System-GMM PVAR Causality Results}

For the global level, the causal relationship between participation in GVCs, renewable energy consumption and $\mathrm{CO}_{2}$ emissions is shown in Panel A of Table 2. The results show that the participation in GVCs negatively causes renewable energy consumption at the $1 \%$ level of significance, which indicates that renewable energy consumption decreases $0.0637 \%$ when participation in GVCs increases by $1 \%$. Additionally, participation in GVCs positively causes $\mathrm{CO}_{2}$ emissions, which implies that a $1 \%$ increase in participation in GVCs increases the $\mathrm{CO}_{2}$ emissions by $0.0313 \%$. This result supports the finding of De Vries and Ferrarini [82], who found that a substantial share of $\mathrm{CO}_{2}$ emissions growth in emerging countries accounted for increasing participation in GVCs, and contradicts the findings of Sun et al. [83], who found that the promotion of participation in GVCs could reduce $\mathrm{CO}_{2}$ emissions significantly in developing countries compared with those in developed countries. Panel A of Table 2 also shows that renewable energy consumption does not cause the participation in GVCs and the $\mathrm{CO}_{2}$ emissions. $\mathrm{CO}_{2}$ emissions cause the participation in GVCs and the relationship is negative at the $10 \%$ level of significance. This suggests that a $1 \%$ increase in $\mathrm{CO}_{2}$ emissions will decrease the participation in GVCs by $0.0620 \%$. Additionally, $\mathrm{CO}_{2}$ emissions do not cause renewable energy consumption. This evidence is inconsistent with the finding of Bhattacharya et al. [72] who found that the growth of renewable energy consumption had a significant negative effect on $\mathrm{CO}_{2}$ emissions in 85 developed and developing countries.

Table 2. Estimated causality results from the dynamic panel System-GMM.

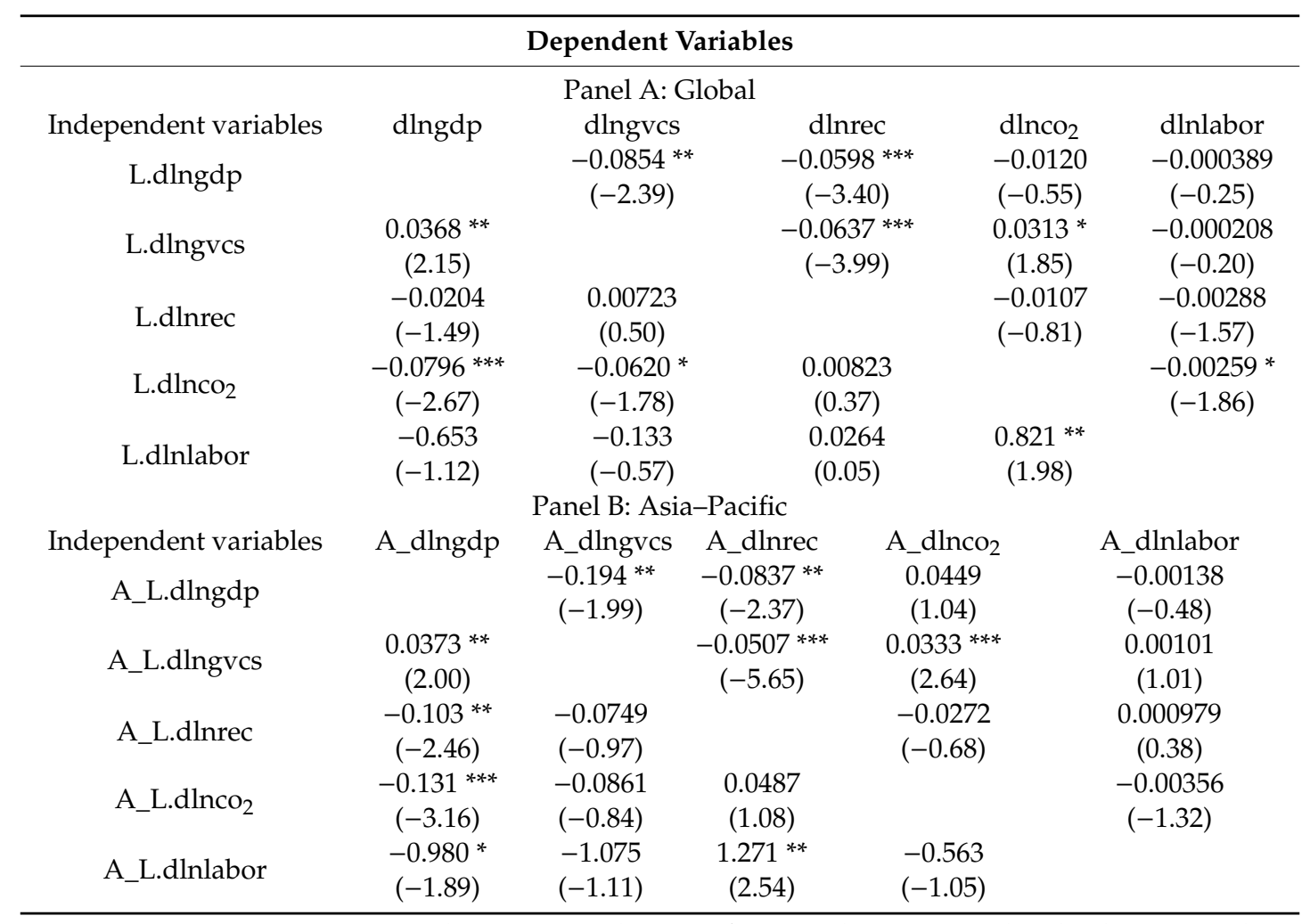

Notes: t-statistics are given in parentheses. ${ }^{*},{ }^{* *},{ }^{* * *}$ show significance at the $10 \%, 5 \%$ and $1 \%$ levels, respectively. 
Panel B of Table 2 shows the causal relationship between participation in GVCs, renewable energy consumption and $\mathrm{CO}_{2}$ emissions for the Asia-Pacific region. First, the results show that the participation in GVCs negatively causes renewable energy consumption and the relationship is significant at the $1 \%$ level. This suggests that a $1 \%$ increase in participation in GVCs will decrease renewable energy consumption by $0.0507 \%$ in Asia-Pacific region. In addition, the results also show that participation in GVCs positively causes $\mathrm{CO}_{2}$ emissions, and the relationship is significant at the $1 \%$ level. This indicates that $1 \%$ increase in participation in GVCs will increase $\mathrm{CO}_{2}$ emissions by $0.0333 \%$ in the Asia-Pacific region. Besides, renewable energy consumption does not cause the participation in GVCs and $\mathrm{CO}_{2}$ emissions. This implies that there are not causal effects of renewable energy consumption on participation in GVCs and $\mathrm{CO}_{2}$ emissions. Furthermore, the results also show that $\mathrm{CO}_{2}$ emissions do not cause the participation in GVCs. This suggests that an increase in $\mathrm{CO}_{2}$ emissions does not influence the participation in GVCs of countries in the Asia-Pacific region. $\mathrm{CO}_{2}$ emissions also do not cause renewable energy consumption. This empirical result contradicts the finding of Dong et al. [66] and Liu et al. [63] who proposed that renewable energy consumption has a negative impact on $\mathrm{CO}_{2}$ emissions, and that there is a feedback causalities between $\mathrm{CO}_{2}$ emissions and renewable energy consumption in four selected countries of the Association of Southeast Asian Nations.

Panel A of Table 3 presents the causality between participation in GVCs, renewable energy consumption and $\mathrm{CO}_{2}$ emissions in the Caribbean-Latin America. The results show that the participation in GVCs causes renewable energy consumption and the relationship is negative at the level of $10 \%$ significance. This indicates that renewable energy consumption will decrease by $0.0698 \%$ when participation in GVCs increases by one percent. However, participation in GVCs does not cause $\mathrm{CO}_{2}$ emissions. From Panel A of Table 3, renewable energy consumption does not cause participation in GVCs. This implies that there is no causal effect of renewable energy consumption on participation in GVCs in Caribbean-Latin America. Renewable energy consumption also does not cause the $\mathrm{CO}_{2}$ emissions. In addition, Panel A of Table 3 also shows that $\mathrm{CO}_{2}$ emissions do not cause the participation in GVCs and renewable energy consumption. This suggests that $\mathrm{CO}_{2}$ emissions do not have casual effects on participation in GVCs and renewable energy consumption.

Panel B of Table 3 presents the causal relationship between participation in GVCs, renewable energy consumption and $\mathrm{CO}_{2}$ emissions in the Middle East and North America (MENA). The estimated results show that the participation in GVCs does not cause renewable energy consumption and $\mathrm{CO}_{2}$ emissions. Renewable energy consumption causes the participation in GVCs and the relationship is positive at the level of $1 \%$ significance. This indicates that one percent increase in renewable energy consumption would increase the participation in GVCs of countries in MENA by $0.0551 \%$. However, renewable energy consumption does not cause $\mathrm{CO}_{2}$ emissions. Panel B of Table 3 also shows that $\mathrm{CO}_{2}$ emissions do not cause participation in GVCs and renewable energy consumption. Thus, $\mathrm{CO}_{2}$ emissions have no causal effects on participation in GVCs and renewable energy consumption in MENA. This empirical evidence collaborates the findings of Charfeddine and Kahia [4] who found that renewable energy consumption has a slight influence on $\mathrm{CO}_{2}$ emissions in MENA.

Panel C of Table 3 describes the causal relationship between participation in GVCs, renewable energy consumption and $\mathrm{CO}_{2}$ emissions in sub-Saharan Africa. The empirical results show that the participation in GVCs does not cause renewable energy consumption and $\mathrm{CO}_{2}$ emissions. That suggests that an increase in participation in GVCs would not affect renewable energy consumption and the $\mathrm{CO}_{2}$ emissions in sub-Saharan Africa. From Panel C of Table 3, renewable energy consumption does not cause the participation in GVCs and $\mathrm{CO}_{2}$ emissions, which implies that renewable energy consumption has no causal effects on participation in GVCs and $\mathrm{CO}_{2}$ emissions in sub-Saharan Africa. In addition, the result also shows that $\mathrm{CO}_{2}$ emissions cause the participation in GVCs and the relationship is negative at the level of $5 \%$. Thus, one percent increase in $\mathrm{CO}_{2}$ emissions will decrease the participation in GVCs by $0.139 \%$. On the contrary, $\mathrm{CO}_{2}$ emissions do not cause renewable energy consumption, which implies that an increase in $\mathrm{CO}_{2}$ emissions would not influence renewable energy consumption. 
This result is inconsistent with the finding of Zoundi [71] who found that renewable energy had a negative effect on $\mathrm{CO}_{2}$ emissions in 25 selected African countries.

Table 3. Estimated causality results from the dynamic panel System-GMM.

\begin{tabular}{|c|c|c|c|c|c|}
\hline \multicolumn{6}{|c|}{ Dependent Variables } \\
\hline \multicolumn{6}{|c|}{ Panel A: Caribbean-Latin America } \\
\hline Independent variables & C_dlngdp & C_dlngves & C_dlnrec & $\mathrm{C}_{-} \mathrm{dln} \mathrm{CO}_{2}$ & C_dlnlabor \\
\hline C_L.dlngdp & & $\begin{array}{c}-0.0822 * \\
(-1.90)\end{array}$ & $\begin{array}{c}-0.0441 \text { * } \\
(-1.78)\end{array}$ & $\begin{array}{r}0.0509 \\
(1.24)\end{array}$ & $\begin{array}{c}0.00435 \\
(0.87)\end{array}$ \\
\hline C_L.dlngves & $\begin{array}{c}0.0349 \\
(0.80)\end{array}$ & & $\begin{array}{c}-0.0698 * \\
(-1.88)\end{array}$ & $\begin{array}{c}-0.00824 \\
(-0.21)\end{array}$ & $\begin{array}{c}0.000585 \\
(0.15)\end{array}$ \\
\hline C_L.dlnrec & $\begin{array}{c}0.0244 \\
(0.64)\end{array}$ & $\begin{array}{c}-0.0406 \\
(-1.18)\end{array}$ & & $\begin{array}{c}-0.00827 \\
(-0.19)\end{array}$ & $\begin{array}{c}-0.000917 \\
(-0.28)\end{array}$ \\
\hline $\mathrm{C}_{-}$L.dlnco 2 & $\begin{array}{c}-0.0922 * * * \\
(-3.39)\end{array}$ & $\begin{array}{l}-0.0439 \\
(-1.15)\end{array}$ & $\begin{array}{c}0.0431 \\
(1.38)\end{array}$ & & $\begin{array}{c}-0.0108^{* * *} \\
(-2.85)\end{array}$ \\
\hline C_L.dlnlabor & $\begin{array}{c}-1.226^{* *} \\
(-2.08)\end{array}$ & $\begin{array}{l}0.178 \\
(0.70)\end{array}$ & $\begin{array}{l}-0.458 \\
(-1.62)\end{array}$ & $\begin{array}{c}1.634^{* *} \\
(2.44)\end{array}$ & \\
\hline \multicolumn{6}{|c|}{ Panel B: Middle East North Africa (MENA) } \\
\hline Independent variables & M_dlngdp & M_dlngvcs & M_dlnrec & M_dlnco 2 & M_dlnlabor \\
\hline M_L.dlngdp & & $\begin{array}{c}-0.439 * * * \\
(-7.23)\end{array}$ & $\begin{array}{c}-0.0206 \\
(-0.14)\end{array}$ & $\begin{array}{c}-0.191 \text { *** } \\
(-2.85)\end{array}$ & $\begin{array}{c}-0.00603 \\
(-1.13)\end{array}$ \\
\hline M_L.dlngves & $\begin{array}{l}0.0609 \\
(1.41)\end{array}$ & & $\begin{array}{l}-0.133 \\
(-1.00)\end{array}$ & $\begin{array}{c}0.00221 \\
(0.04)\end{array}$ & $\begin{array}{c}-0.00168 \\
(-0.35)\end{array}$ \\
\hline M_L.dlnrec & $\begin{array}{c}0.0113 \\
(0.50)\end{array}$ & $\begin{array}{c}0.0551^{* * *} \\
(2.64)\end{array}$ & & $\begin{array}{c}0.00458 \\
(0.12)\end{array}$ & $\begin{array}{c}0.00272 \\
(1.57)\end{array}$ \\
\hline M_L.dlnco 2 & $\begin{array}{c}-0.273^{* * * *} \\
(-5.29)\end{array}$ & $\begin{array}{c}0.0412 \\
(0.66)\end{array}$ & $\begin{array}{l}0.250 \\
(1.59)\end{array}$ & & $\begin{array}{c}0.00241 \\
(0.46)\end{array}$ \\
\hline M_L.dlnlabor & $\begin{array}{l}-0.268 \\
(-0.35)\end{array}$ & $\begin{array}{c}-2.384^{* * *} \\
(-2.83)\end{array}$ & $\begin{array}{c}-5.742^{* * *} \\
(-2.66)\end{array}$ & $\begin{array}{c}-3.773^{* * *} \\
(-3.46)\end{array}$ & \\
\hline \multicolumn{6}{|c|}{ Panel C: Sub-Saharan Africa } \\
\hline Independent variables & S_dlngdp & S_dlngves & S_dlnrec & $\mathrm{S}_{-} \mathrm{dln} \mathrm{CO}_{2}$ & S_dlnlabor \\
\hline S_L.dlngdp & & $\begin{array}{c}0.00277 \\
(0.05)\end{array}$ & $\begin{array}{c}-0.0114 \\
(-1.28)\end{array}$ & $\begin{array}{c}-0.0690 * * \\
(-1.99)\end{array}$ & $\begin{array}{c}0.000317 \\
(0.26)\end{array}$ \\
\hline S_L.dlngves & $\begin{array}{c}0.00520 \\
(0.20)\end{array}$ & & $\begin{array}{c}0.00473 \\
(0.76)\end{array}$ & $\begin{array}{l}-0.0147 \\
(-0.52)\end{array}$ & $\begin{array}{c}0.0000974 \\
(0.12)\end{array}$ \\
\hline S_L.dlnrec & $\begin{array}{c}0.0628 \\
(0.61)\end{array}$ & $\begin{array}{c}-0.0812 \\
(-0.48)\end{array}$ & & $\begin{array}{c}0.000732 \\
(0.01)\end{array}$ & $\begin{array}{c}0.00935 \\
(1.50)\end{array}$ \\
\hline S_L.dlnco 2 & $\begin{array}{l}0.0355 \\
(0.80)\end{array}$ & $\begin{array}{c}-0.139 * * \\
(-2.48)\end{array}$ & $\begin{array}{c}0.00720 \\
(0.52)\end{array}$ & & $\begin{array}{c}0.000487 \\
(0.45)\end{array}$ \\
\hline S_L.dlnlabor & $\begin{array}{l}1.556 \\
(1.63)\end{array}$ & $\begin{array}{c}10.82^{* * *} \\
(2.97)\end{array}$ & $\begin{array}{c}1.266^{* * * *} \\
(3.02)\end{array}$ & $\begin{array}{c}-5.069 * * * \\
(-2.64)\end{array}$ & \\
\hline
\end{tabular}

Notes: t-statistics are given in parentheses. ${ }^{*}, * * * * *$ show significance at the $10 \%, 5 \%$ and $1 \%$ levels, respectively.

\subsection{Variance Decomposition}

In order to specify the degree of mutual dynamic effects between variables, in this section we use the forecast error variance decomposition method of the PVAR model to present the first 10 years of variance decomposition (see Appendix B for the variance decomposition). However, before the analysis of forecast error variance decomposition and impulse response functions, the stability of the PVAR model must be test. Referring to the studies of Hamilton [84], Lütkepohl [85] and Abrigo and Love [86], the model is stable only when the modulus of all eigenvalues of the adjoint matrix is less than one. The stability graphs (see Appendix $C$ for the stability graphs) show that the characteristic roots are all less than one and all fall within the unit circle at both global and regional levels, which indicates that the PVAR models in this paper are all stable.

For the global level, only $0.020 \%$ of the forecast error variance of participation in GVCs after ten periods can be explained by shocks in renewable energy consumption, while $0.174 \%$ of the forecast error 
variance of participation in GVCs is explained by shocks in $\mathrm{CO}_{2}$ emissions. After ten years forecast, around $0.482 \%$ of the forecast error variance of renewable energy consumption can be explained by disturbances in participation in GVCs, while around $0.006 \%$ can be explained by shocks in $\mathrm{CO}_{2}$ emissions. Shocks in participation in GVCs appear to have minimal effect (only $0.262 \%$ ) in forecasting $\mathrm{CO}_{2}$ emissions, while shocks in renewable energy consumption appear to have a more important impact (3.187\%) in forecasting $\mathrm{CO}_{2}$ emissions.

In the Asia-Pacific region, the variance contribution of renewable energy consumption and $\mathrm{CO}_{2}$ emissions to participation in GVC shocks are $0.028 \%$ and $0.135 \%$. A shock to participation in GVCs accounts for $2.644 \%$ of the variance in energy consumption, and it accounts for $0.262 \%$ of the variance in $\mathrm{CO}_{2}$ emissions. This result indicates that renewable energy consumption and $\mathrm{CO}_{2}$ emissions appear to have insignificant or minor effects on participation in GVCs, while the participation in GVCs seems to have some impact in renewable energy consumption.

In the Caribbean-Latin America region, around 0.094\% of the variance of participation in GVCs is explained by shocks in renewable energy consumption, and around $0.250 \%$ can be explained by shocks in $\mathrm{CO}_{2}$ emissions; $0.835 \%$ of the variance of renewable energy consumption is attributed to shocks in participation in GVCs, and $0.194 \%$ of the variance of renewable energy consumption is attributed to shocks in $\mathrm{CO}_{2}$ emissions. The variance contribution of participation in GVCs and renewable energy consumption and to $\mathrm{CO}_{2}$ emission shocks are $1.138 \%$ and $5.881 \%$, respectively.

In the MENA region, a disturbance to renewable energy consumption accounts for only $0.653 \%$ of forecast error variance in participation in GVCs, and a disturbance to $\mathrm{CO}_{2}$ emissions accounts for only $0.730 \%$ of the variance in participation in GVCs. This means that renewable energy, renewable consumption and $\mathrm{CO}_{2}$ emissions appear to have insignificant or minor effects on participation in GVCs in the short and long run. In contrast, $3.181 \%$ of variance of renewable energy consumption after ten periods can be explained by the disturbances in participation in GVCs.

In the sub-Saharan Africa region, a shock to renewable energy consumption accounts for $0.169 \%$ of the forecast error variance in participation in GVCs, and a shock to $\mathrm{CO}_{2}$ emissions accounts for $1.164 \%$ of the variance in participation in GVCs. Additionally, around $0.976 \%$ of the variance of renewable energy consumption is explained by disturbances in participation in GVCs and $0.016 \%$ from disturbances in $\mathrm{CO}_{2}$ emissions, while the variance contribution of participation in GVCs and renewable energy consumption and to $\mathrm{CO}_{2}$ emissions' shocks are $1.649 \%$ and $14.783 \%$.

\subsection{Impulse-Response Function (IRF) Analysis}

This section portrays the results of impulse response functions (IRFs) of economic growth, participation in GVCs, renewable energy consumption, $\mathrm{CO}_{2}$ emissions and labor force, and we focus on the three variables of participation in GVCs, renewable energy consumption and $\mathrm{CO}_{2}$ emissions using the Monte Carlo method to simulate the process 200 times. The IRFs proposed by Love and Zicchino [79] characterize the impact of adding a standard deviation to the error term on the current and future values of other endogenous variables while holding other variables unchanged. However, due to the uncertainty of variance-covariance of errors orthogonality, it is important to ensure the orthogonalization of shocks based on the Cholesky decomposition of variance-covariance matrix residues [87]. Thus, it is necessary to determine the order of variables on the basis of their endogeneity. Sims [87] considered that more exogenous and affect the following variables simultaneously or even with a lag should come out earlier; nevertheless, the variables coming out later are more endogenous and affect foregoing variables only with a lag. According to this and preceding studies, we ensured the order of variables in this paper as follows: economic growth, participation in GVCs, renewable energy consumption, $\mathrm{CO}_{2}$ emissions and labor force. Economic growth may affect participation in GVCs, renewable energy consumption and $\mathrm{CO}_{2}$ emissions contemporaneously or even with a lag, whereas renewable energy consumption and $\mathrm{CO}_{2}$ emissions may affect the economic growth and participation in GVCs only with a lag. 
Figure 1 shows the global impulse response functions, which reports that the responses of participation in GVCs to one standard deviation shock of renewable energy consumption is positive, which initially increases and then decreases and stabilizes in the long run from year 2 to 10. More precisely, the maximum positive effect occurs in the first year with the value equal to about 0.002 . On the contrary, a shock in $\mathrm{CO}_{2}$ emissions will decrease participation in GVCs firstly and then increase it and eventually stabilize. The maximum negative effect also occurs in the first year. The responses of $\mathrm{CO}_{2}$ emissions as the result of one standard deviation shock to participation in GVCs initially increase and then decrease and stabilize in the long run, while the responses of renewable energy consumption as the result of one standard deviation shock to participation in GVCs initially decrease and then increase and stabilize in the long run from year 2 to 10.

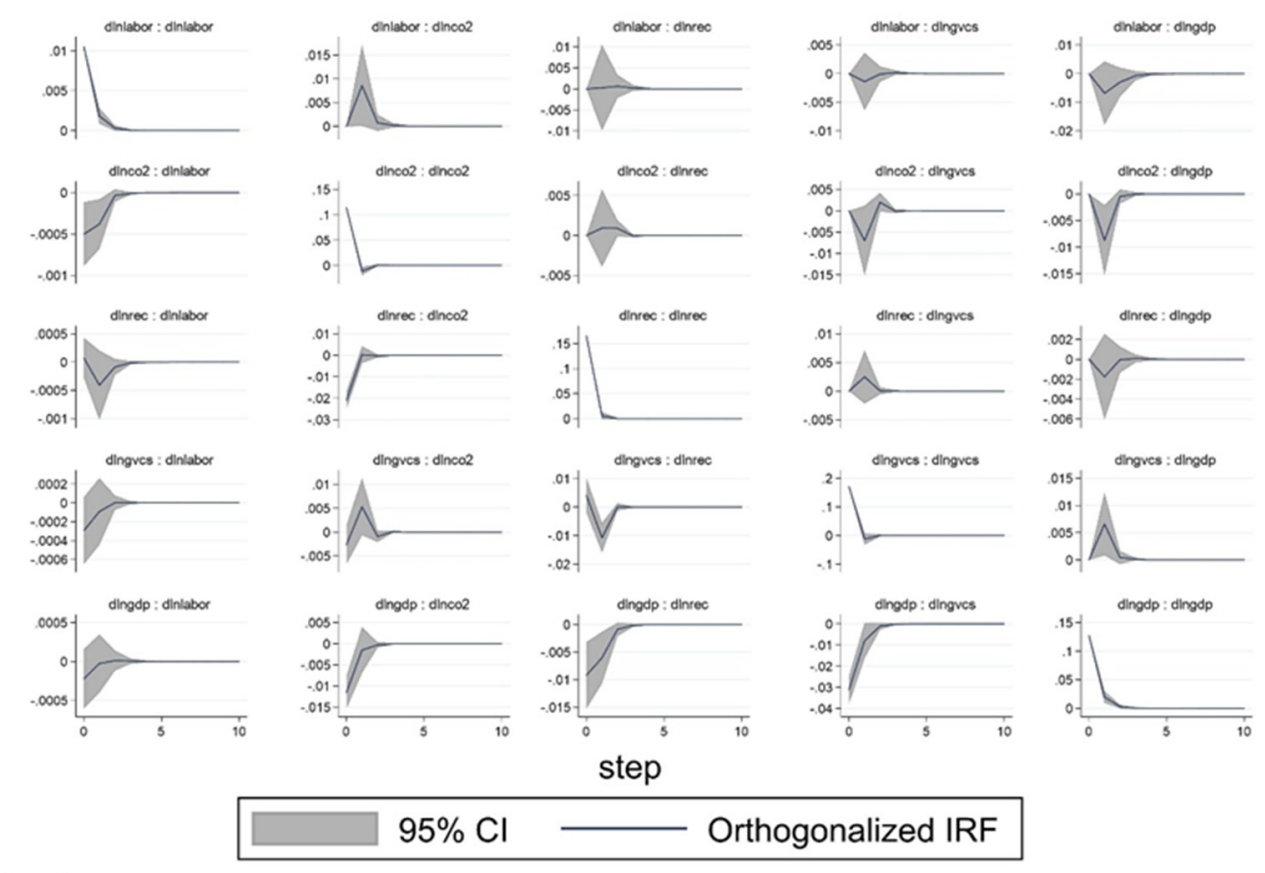

impulse : response

Figure 1. Global impulse response functions.

In Figure 2, participation in GVCs will have a negative response to a standard deviation shock in renewable energy consumption and $\mathrm{CO}_{2}$ emissions in the Asia-Pacific region in period 0 and 1 but the response is equal to zero from 2 to 10 . More precisely, the maximum negative effects all occur in the first year with the value equal to about 0.005 and 0.01 , respectively. This is consistent with the PVAR estimation that the contributions of renewable energy consumption and $\mathrm{CO}_{2}$ emissions to participation in GVCs are very weak in Asia-Pacific. In addition, the response of $\mathrm{CO}_{2}$ emissions to one standard deviation shock in participation in GVCs is positive and it is strongly positive in the first year. The response of renewable energy consumption to one standard deviation shock in participation in GVCs is positive at 0 and negative in the first year and stabilizes in the long run from 2 to 10.

Figure 3 presents the Caribbean-Latin America impulse response functions, in which a positive shock to renewable energy consumption has a negative effect on the participation in GVCs at the first year and then positive in the second year, and the effects of shocks entirely die after three years. The maximum effect occurs in the first year. Similarly, the impact of a one standard deviation shock in $\mathrm{CO}_{2}$ emissions on participation in GVCs is negative in the first year and positive in the second. Furthermore, the maximum impact also appears in the first year. The response of renewable energy consumption to a one standard deviation shock of participation in GVCs initially decreases and then increases and stabilizes in the long run from 3 to 10 . The response of $\mathrm{CO}_{2}$ emissions to one standard 
deviation shock in the participation in GVCs is instantaneously negative but positive in the first year and equal to 0 from year 2 to 10 .
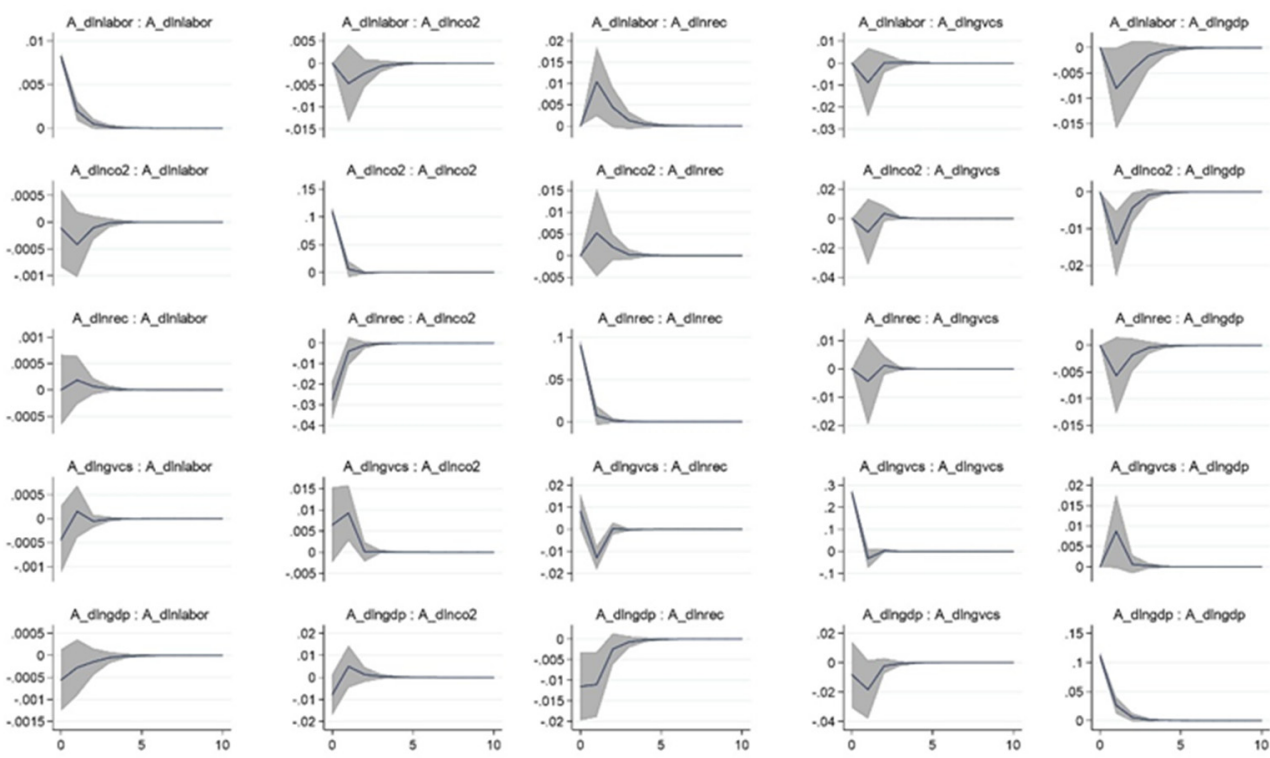

step

$95 \% \mathrm{Cl}$

Orthogonalized IRF

impulse : response

Figure 2. Asia-Pacific impulse response function.
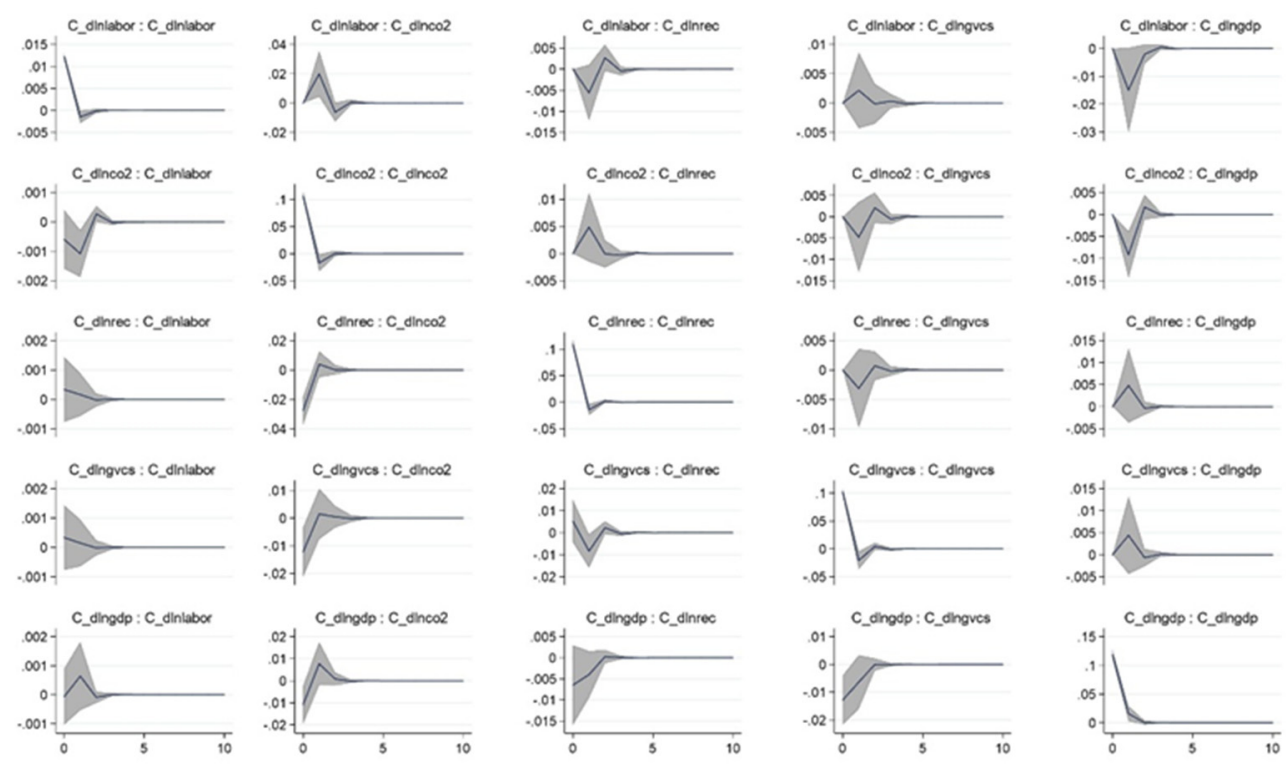

$95 \% \mathrm{Cl}$

Orthogonalized IRF

impulse : response

Figure 3. Caribbean-Latin America impulse response function. 
The MENA impulse response functions are shown in the Figure 4. Figure 4 shows that the response of the participation in GVCs to a one standard deviation shock in the growth of renewable energy consumption initially increases and then decreases and later increases and equals zero from year 3 to 10. The response of participation in GVCs to a one standard deviation shock of $\mathrm{CO}_{2}$ emissions is positive in the first two years and then negative in the third year and later equal to 0 from year 5 to 10. Additionally, the responses of renewable energy consumption to a one standard deviation shock in participation in GVCs are instantaneously positive but negative at the first year and equal to 0 from year 3 to 10. The response of $\mathrm{CO}_{2}$ emissions to a one standard deviation shock in participation in GVCs is positive in the first year and weakly negative in the second year, and the effect dies after a weakly positive response in the third year.
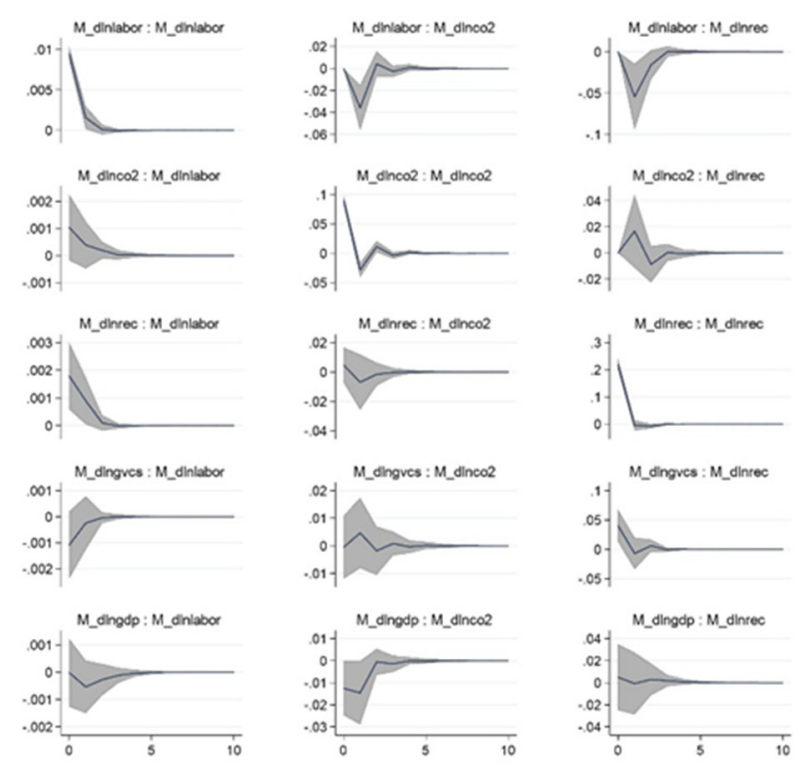

step
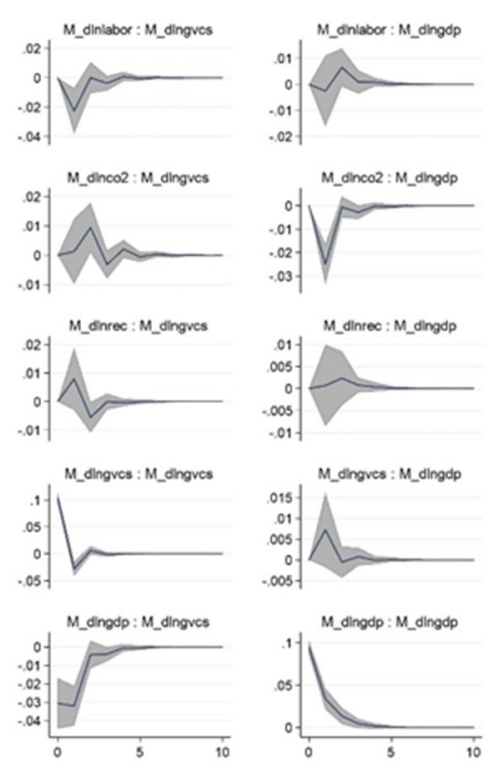

$95 \% \mathrm{Cl} \longrightarrow$ Orthogonalized IRF

impulse : response

Figure 4. MENA impulse response functions.

From the sub-Saharan Africa impulse response functions in Figure 5, the reaction of participation in GVCs to one standard shock in renewable energy consumption is positive for the whole period (up to ten years), and the maximum positive impact occurs in the first year with the value approximately equal to 0.01 . The reaction of participation in GVCs to a one standard deviation shock in $\mathrm{CO}_{2}$ emissions is strongly negative in the first year with a value of about 0.02 . The impact dies after three years after a weakly positive response in the second year. The response of $\mathrm{CO}_{2}$ emissions to one standard deviation shock in participation in GVCs is negative from year 0 to 1 and equal to zero from year 1 to 10. The reaction of renewable energy consumption to a one standard deviation shock in participation in GVCs is positive for the whole period and then stabilizes from the first year. 

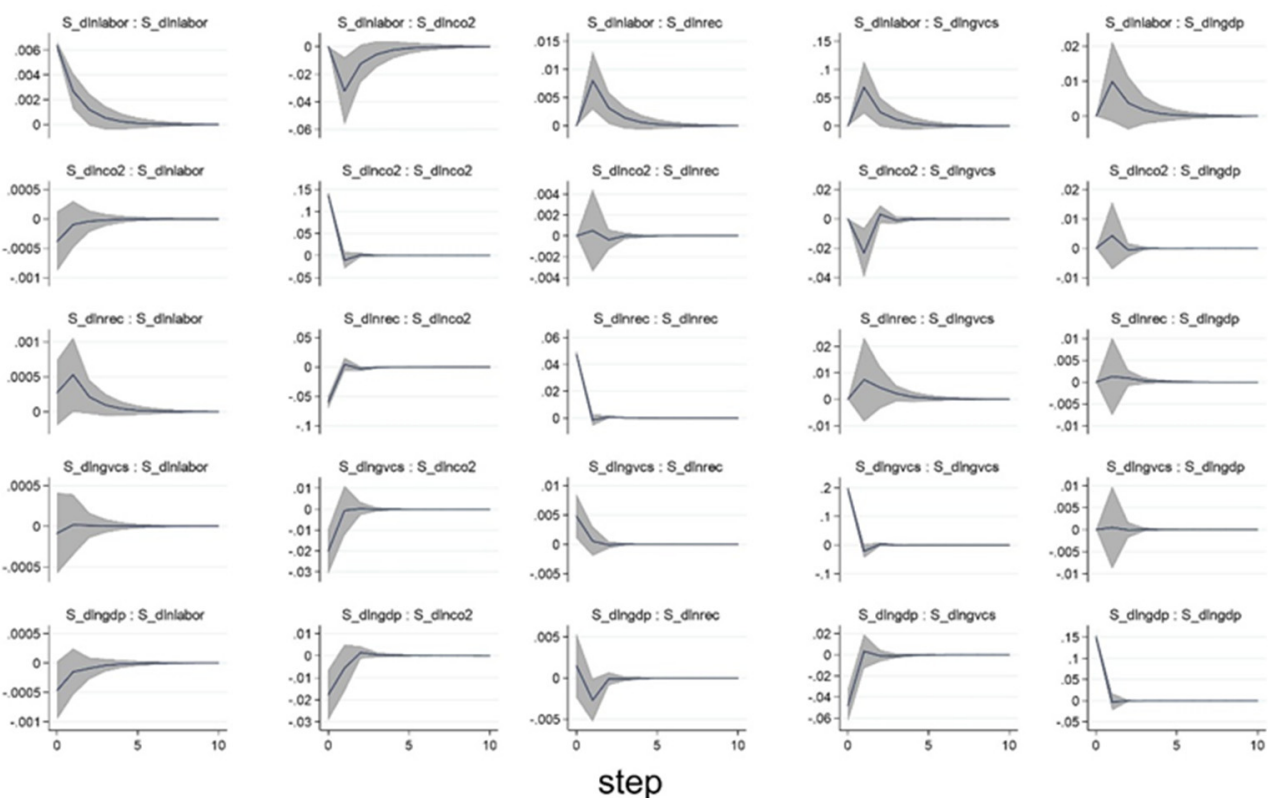

$95 \% \mathrm{Cl}$

Orthogonalized IRF

impulse : response

Figure 5. Sub-Saharan Africa impulse response functions.

\subsection{Robustness Check}

In order to check the robustness of the previous analysis, we conducted the panel Granger causality test. The results from the test revealed the same direction of causal relationships between participation in GVCs, renewable energy consumption and $\mathrm{CO}_{2}$ emissions.

From Tables 4 and 5 the participation in GVCs granger causes renewable energy consumption at the global level and in the Asia-Pacific, Caribbean-Latin America region, whereas all were without feedback. Renewable energy consumption causes the participation in GVCs in MENA region without feedback inversely. There is a bidirectional causality between participation in $\mathrm{GVCs}$ and $\mathrm{CO}_{2}$ emissions at the global level. However, there is only a unidirectional causal relationship running from $\mathrm{CO}_{2}$ emissions to participation in GVCs in selected sub-Saharan Africa countries and from participation in GVCs to $\mathrm{CO}_{2}$ emissions in Asia-Pacific region. Additionally, there is no causality between renewable energy consumption and $\mathrm{CO}_{2}$ emissions at global and regional levels.

Table 4. Panel Granger causality tests.

\begin{tabular}{cccccc}
\hline \multicolumn{5}{c}{ Dependent Variables } \\
\hline \multirow{5}{*}{ Independent variables } & dlngdp & dlngvcs & dlnrec & dlnco 2 & dlnlabor \\
L.dlngdp & & $5.725^{* *}$ & $11.532^{* * *}$ & 0.299 & 0.060 \\
& & $(0.017)$ & $(0.001)$ & $(0.585)$ & $(0.806)^{* *}$ \\
L.dlngvcs & $4.602^{* *}$ & & $15.902^{* * *}$ & $3.418^{*}$ & 0.041 \\
& $(0.032)$ & & $(0.000)$ & $(0.064)$ & $(0.839)$ \\
L.dlnrec & 2.216 & 0.247 & & 0.659 & 2.453 \\
& $(0.137)$ & $(0.619)$ & & $(0.417)$ & $(0.117)$ \\
L.dlnco 2 & $7.111^{* * *}$ & $3.163 *$ & 0.137 & & $3.462 *$ \\
& $(0.008)$ & $(0.075)$ & $(0.711)$ & & $(0.063)$ \\
L.dlnlabor & 1.259 & 0.325 & 0.003 & $3.904 * *$ & \\
& $(0.262)$ & $(0.569)$ & $(0.959)$ & $(0.048)$ & \\
\hline
\end{tabular}


Table 4. Cont.

\begin{tabular}{|c|c|c|c|c|c|}
\hline \multicolumn{6}{|c|}{ Dependent Variables } \\
\hline & & Asia-Pacific & & & \\
\hline Independent variables & A_dlngdp & A_dlngves & A_dlnrec & A_dlnco 2 & A_dlnlabor \\
\hline \multirow{2}{*}{ L.A_dlngdp } & & $3.949 * *$ & $5.634^{* *}$ & 1.074 & 0.226 \\
\hline & & $(0.047)$ & $(0.018)$ & $(0.300)$ & $(0.634)$ \\
\hline \multirow{2}{*}{ L.A_dlngves } & $3.989 * *$ & & $31.973 * * *$ & $6.962^{* * *}$ & 1.015 \\
\hline & $(0.046)$ & & $(0.000)$ & $(0.008)$ & $(0.314)$ \\
\hline \multirow{2}{*}{ L.A_dlnrec } & $6.030 * *$ & 0.933 & & 0.461 & 0.144 \\
\hline & $(0.014)$ & $(0.334)$ & & $(0.497)$ & $(0.704)$ \\
\hline \multirow{2}{*}{ L.A_dlnco 2} & $10.004^{* * *}$ & 0.712 & 1.167 & & 1.730 \\
\hline & $(0.002)$ & $(0.399)$ & $(0.280)$ & & $(0.188)$ \\
\hline \multirow{2}{*}{ L.A_dlnlabor } & $3.566^{*}$ & 1.240 & $6.432 * *$ & 1.111 & \\
\hline & $(0.059)$ & $(0.265)$ & $(0.011)$ & $(0.292)$ & \\
\hline \multicolumn{6}{|c|}{ Caribbean-Latin America } \\
\hline Independent variables & C_dlngdp & C_dlngves & C_dlnrec & $\mathrm{C}_{-} \mathrm{dln} \mathrm{CO}_{2}$ & C_dlnlabor \\
\hline \multirow{2}{*}{ L.C_dlngdp } & & $3.597 *$ & $3.179 *$ & 1.535 & 0.764 \\
\hline & & $(0.058)$ & $(0.075)$ & $(0.215)$ & $(0.382)$ \\
\hline \multirow{2}{*}{ L.C_lngvcs } & 0.647 & & $3.544 *$ & 0.043 & 0.023 \\
\hline & $(0.421)$ & & $(0.060)$ & $(0.836)$ & $(0.879)$ \\
\hline \multirow{2}{*}{ L.C_dlnrec } & 0.405 & 1.403 & & 0.037 & 0.077 \\
\hline & $(0.524)$ & $(0.236)$ & & $(0.847)$ & $(0.781)$ \\
\hline \multirow{2}{*}{ L.C_lnco 2} & $11.509 * * *$ & 1.325 & 1.896 & & $8.151^{* * *}$ \\
\hline & $(0.001)$ & $(0.250)$ & $(0.168)$ & & $(0.004)$ \\
\hline \multirow{2}{*}{ L.C_lnlabor } & $4.313^{* *}$ & 0.484 & 2.629 & $5.943^{* *}$ & \\
\hline & $(0.038)$ & $(0.487)$ & $(0.105)$ & $(0.015)$ & \\
\hline
\end{tabular}

Notes: Probability values are given in parentheses. ${ }^{*},{ }^{* *},{ }^{* *}$ show significance at the $10 \%, 5 \%$ and $1 \%$ levels, respectively.

Table 5. Panel Granger causality tests.

\begin{tabular}{|c|c|c|c|c|c|}
\hline \multicolumn{6}{|c|}{ Dependent Variables } \\
\hline & & MENA & & & \\
\hline Independent variables & M_dlngdp & M_dlngves & M_dlnrec & M_dlnco 2 & M_dlnlabor \\
\hline L.M_dlngdp & & $\begin{array}{c}52.334^{* * *} \\
(0.000)\end{array}$ & $\begin{array}{c}0.019 \\
(0.892)\end{array}$ & $\begin{array}{c}8.123^{* * *} \\
(0.004)\end{array}$ & $\begin{array}{c}1.278 \\
(0.258)\end{array}$ \\
\hline L.M_lngvcs & $\begin{array}{c}1.980 \\
(0.159)\end{array}$ & & $\begin{array}{c}1.000 \\
(0.317)\end{array}$ & $\begin{array}{c}0.001 \\
(0.972)\end{array}$ & $\begin{array}{c}0.120 \\
(0.729)\end{array}$ \\
\hline L.M_dlnrec & $\begin{array}{c}0.253 \\
(0.615)\end{array}$ & $\begin{array}{l}6.985^{* * *} \\
(0.008)\end{array}$ & & $\begin{array}{c}0.014 \\
(0.905)\end{array}$ & $\begin{array}{c}2.449 \\
(0.118)\end{array}$ \\
\hline L.M_lnco 2 & $\begin{array}{c}27.992^{* * * *} \\
(0.000)\end{array}$ & $\begin{array}{c}0.433 \\
(0.510)\end{array}$ & $\begin{array}{c}2.529 \\
(0.112)\end{array}$ & & $\begin{array}{c}0.212 \\
(0.645)\end{array}$ \\
\hline L.M_lnlabor & $\begin{array}{c}0.120 \\
(0.729)\end{array}$ & $\begin{array}{c}8.010^{* * *} \\
(0.005)\end{array}$ & $\begin{array}{c}7.068^{* * *} \\
(0.008)\end{array}$ & $\begin{array}{c}11.945^{* * * *} \\
(0.001)\end{array}$ & \\
\hline \multicolumn{6}{|c|}{ Sub-Saharan Africa } \\
\hline Independent variables & S_dlngdp & S_dlngves & S_dlnrec & $\mathrm{S}_{\text {_dlnco }}$ & S_dlnlabor \\
\hline L.S_dlngdp & & $\begin{array}{c}0.002 \\
(0.960)\end{array}$ & $\begin{array}{l}1.640 \\
(0.200)\end{array}$ & $\begin{array}{l}3.950 * * \\
(0.047)\end{array}$ & $\begin{array}{c}0.069 \\
(0.792)\end{array}$ \\
\hline L.S_lngves & $\begin{array}{c}0.040 \\
(0.842)\end{array}$ & & $\begin{array}{c}0.573 \\
(0.449)\end{array}$ & $\begin{array}{c}0.268 \\
(0.605)\end{array}$ & $\begin{array}{c}0.015 \\
(0.904)\end{array}$ \\
\hline L.S_dlnrec & $\begin{array}{c}0.373 \\
(0.541)\end{array}$ & $\begin{array}{c}0.230 \\
(0.631)\end{array}$ & & $\begin{array}{c}0.000 \\
(0.996)\end{array}$ & $\begin{array}{c}2.263 \\
(0.132)\end{array}$ \\
\hline L.S_lnco 2 & $\begin{array}{c}0.638 \\
(0.424)\end{array}$ & $\begin{array}{l}6.130 * * \\
(0.013)\end{array}$ & $\begin{array}{c}0.267 \\
(0.605)\end{array}$ & & $\begin{array}{c}0.207 \\
(0.649)\end{array}$ \\
\hline L.S_lnlabor & $\begin{array}{c}2.660 \\
(0.103)\end{array}$ & $\begin{array}{c}8.825^{* * *} \\
(0.003)\end{array}$ & $\begin{array}{c}9.147^{* * *} \\
(0.002)\end{array}$ & $\begin{array}{c}6.993^{* * *} \\
(0.008)\end{array}$ & \\
\hline
\end{tabular}

Notes: Probability values are given in parentheses. $*, * *, * *$ show significance at the $10 \%, 5 \%$ and $1 \%$ levels, respectively. 


\section{Conclusions}

Based on the previous studies about participation in GVCs, renewable energy consumption and $\mathrm{CO}_{2}$ emissions, this paper firstly employs the PVAR model with the System-GMM approach to examine the causality between participation in GVCs, renewable energy consumption and $\mathrm{CO}_{2}$ emissions, while taking into account the variables of economic growth and labor force using the panel data of 172 countries throughout 1990-2015.

The main conclusions of the PVAR analysis can be summarized in three important points. Firstly, except for sub-Saharan Africa, there is a unidirectional causality between participation in GVCs and renewable energy consumption. Participation in GVCs negatively causes renewable energy consumption at the global level and in the Asia-Pacific and Caribbean-Latin America regions, which indicates that participation in GVCs aiming at accelerating economic development will not be conducive to the development and utilization of renewable energy. Renewable energy consumption positively causes participation in GVCs in MENA, which suggests that renewable energy policies aiming to increasing the use of renewable energy and reducing traditional energy use will promote the participation in the international division of labor. There is no causality between participation in GVCs and renewable energy consumption in sub-Saharan Africa.

Secondly, we also found that the causality between participation in GVCs and $\mathrm{CO}_{2}$ emissions has different aspects in global and regional levels. There is a feedback causal relationship between participation in GVCs and $\mathrm{CO}_{2}$ emissions at the global level. The environmental policies aimed at reducing $\mathrm{CO}_{2}$ emissions will increase the participation in GVCs while GVCs policies, such as industrial innovation policies, will cause environmental degradation. There is a unidirectional causality running from participation in GVCs to $\mathrm{CO}_{2}$ emissions, and participation in GVCs positively causes $\mathrm{CO}_{2}$ emissions in the Asia-Pacific region. This indicates that the GVC policies will lead to environmental damage. There is a unidirectional causality running from $\mathrm{CO}_{2}$ emissions to participation in GVCs, and $\mathrm{CO}_{2}$ emissions negatively cause participation in GVCs in sub-Saharan Africa. This suggests that the environmental policies are beneficial for sub-Saharan African countries to participate in GVCs. However, there is no causality between participation in GVCs and $\mathrm{CO}_{2}$ emissions in Caribbean-Latin America and MENA.

Thirdly, unlike many previous studies, we also found that there is no causal relationship between renewable energy consumption and $\mathrm{CO}_{2}$ emissions both at global and regional levels. This implies that existing renewable energy policies fail to protect the environment, and environmental policies aimed at reducing $\mathrm{CO}_{2}$ emissions also have no effect on the development and use of renewable energy.

From the forecast error variance decomposition, renewable energy consumption and $\mathrm{CO}_{2}$ emissions appear to have a slight effect on participation in GVCs in the short and long run at the global and regional levels. Shocks in participation in GVCs also appear to have minimal effects in forecasting $\mathrm{CO}_{2}$ emissions and renewable energy consumption. In addition, the impulse response results show that with the exception of the MENA region, the overall effect of a one standard deviation shock of $\mathrm{CO}_{2}$ emissions on participation in GVCs is negative, while except for Asia-Pacific and Caribbean-Latin America region, the cumulative effect of a one standard deviation shock of renewable energy consumption on participation in GVCs is positive. For the global level and the Asia-Pacific and MENA regions, the cumulative effect of a one standard deviation shock of participation in GVCs on $\mathrm{CO}_{2}$ emissions is positive, but for the global level and Asia-Pacific and Caribbean-Latin America regions, the overall effect of a one standard deviation shock of participation in GVCs on renewable energy consumption is negative.

Overall, this study demonstrates that there are environmental costs related to GVC policies aiming to participate in the global division of labor. Hence, the implementation of GVCs policies will be a challenge to environment protection. On the contrary, renewable energy policies and environmental protection policies do not have adverse effects on participation in GVCs. To some extent, environmental policies seeking to mitigate $\mathrm{CO}_{2}$ emissions and to increase the use of renewable energy facilitate participation in GVCs. Thus, this investigation argues that reasonable environmental, 
energy and industrial policies should be developed to promote participation in GVCs while protecting the environment. Some of the policy recommendations are as follows.

Firstly, industrial policies aiming to promote participation in GVCs should be executed with care and should consider technological innovation to reduce traditional energy consumption and to accelerate renewable energy consumption. On the one hand, firms should be required to produce intermediate and final products complying with global standards and environmental certifications. On the other hand, since participation in GVCs is an important way to obtain technical information, governments should encourage firms to learn and absorb the environmental knowledge and technology in the process of participation in GVCs.

Besides, given that effective environmental governance can accelerate global competition through GVCs, environmental conservation policies targeting reduction of $\mathrm{CO}_{2}$ emissions and increasing the use of renewable energy should be exercised rigorously. Sound environmental protection laws and regulations need to be developed to strengthen environmental management. At the same time, governments should provide financial support for environmental projects and facilities and offer tax breaks for companies, projects or products that are in line with environmental standards.

Furthermore, considering that renewable energy consumption does not play a role in alleviating $\mathrm{CO}_{2}$ emissions currently, governments should continue the process of energy production and consumption reforms by setting mandatory renewable energy targets and development plans. Additionally, governments should raise funds through multiple channels to support renewable energy development to break through the constraints of inadequate inputs of funds.

Author Contributions: Conceptualization, Z.W., G.H. and B.X.; Data curation, Z.W. and B.X.; Writing-original draft, Z.W.; Writing-review and editing, Z.W., G.H. and B.X. All authors have read and agreed to the published version of the manuscript.

Funding: This research was funded by the National Social Science Foundation of China (No. 16FJY008); the Natural Science Foundation of Shandong Province (Grant No. ZR2016FM26); and the Postgraduate Science and Technology Innovation Foundation of SDUST (No. SDKDYC170228).

Conflicts of Interest: The authors declare no conflict of interest.

\section{Appendix A}

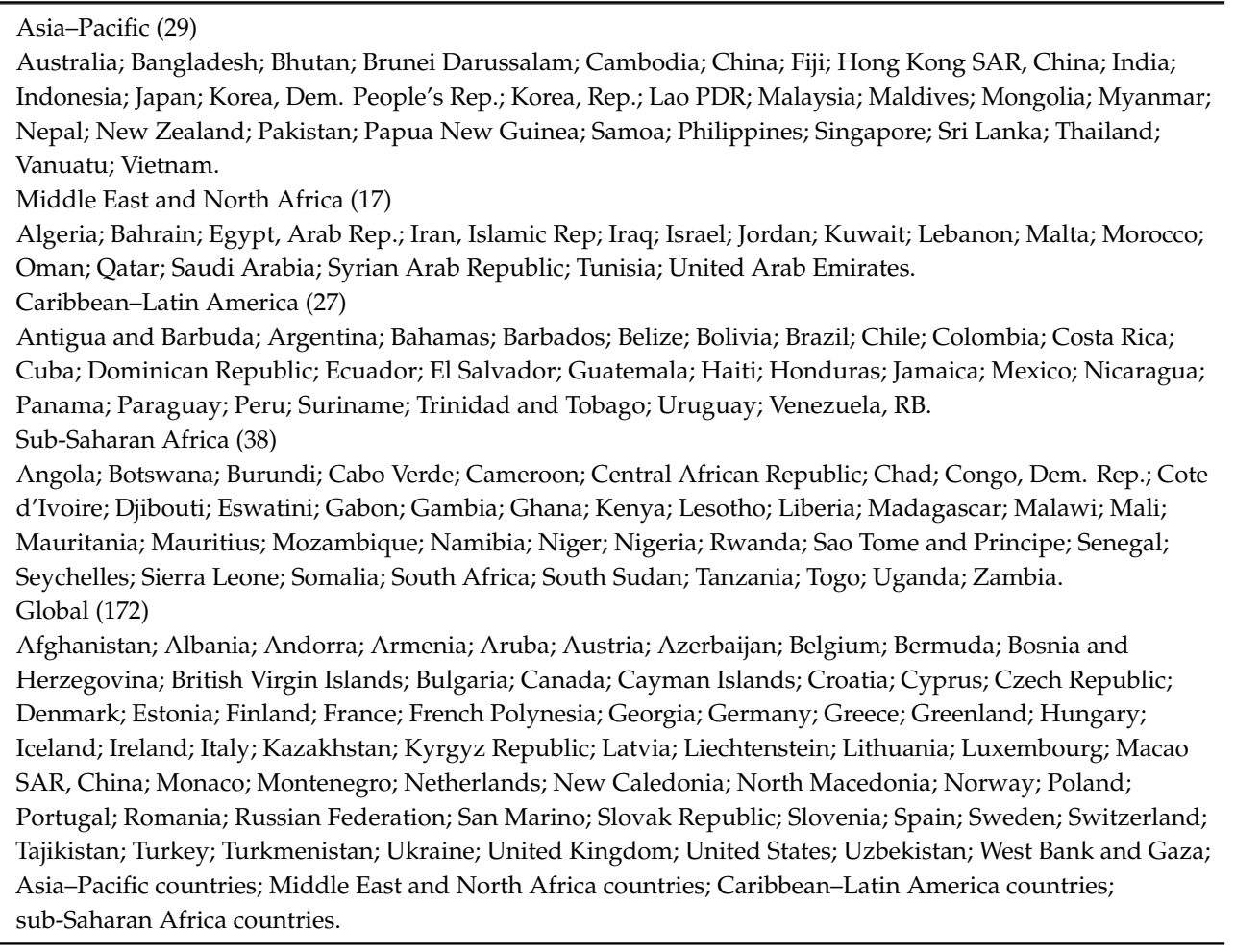




\section{Appendix B}

Table A1. Global variance decomposition.

\begin{tabular}{cccccc}
\hline \multirow{2}{*}{$\begin{array}{c}\text { Forecast } \\
\text { Horizon }\end{array}$} & dlngdp & dlngvcs & dlnrec & dlnco 2 & dlnlabor \\
\cline { 2 - 6 } dlngdp & 1 & 0 & 0 & 0 & 0 \\
1 & 0.9893361 & 0.0025948 & 0.0001838 & 0.0045337 & 0.0033517 \\
5 & 0.989336 & 0.0025948 & 0.0001838 & 0.0045337 & 0.0033517 \\
10 & & & & & \\
dlngvcs & 0.032321 & 0.967679 & 0 & 0 & 0 \\
1 & 0.034139 & 0.963852 & 0.0002032 & 0.0017404 & 0.0000654 \\
5 & 0.034139 & 0.963852 & 0.0002032 & 0.0017404 & 0.0000654 \\
10 & & & & & \\
dlnrec & 0.0031008 & 0.0006187 & 0.9962805 & 0 & 0 \\
1 & 0.0044322 & 0.0048201 & 0.9906688 & 0.0000601 & 0.0000188 \\
5 & 0.0044322 & 0.0048201 & 0.9906688 & 0.0000601 & 0.0000188 \\
10 & & & & & \\
dlnco 2 & 0.0098183 & 0.0005127 & 0.0324005 & 0.9572686 & 0 \\
1 & 0.0098265 & 0.0026184 & 0.0318704 & 0.95025 & 0.0054347 \\
5 & 0.0098265 & 0.0026184 & 0.0318704 & 0.95025 & 0.0054347 \\
10 & & & & & \\
dlnlaboryyyyyy & 0.0004509 & 0.0007894 & 0.0000475 & 0.0022884 & 0.9964238 \\
1 & 0.000443 & 0.0008376 & 0.0015875 & 0.0035019 & 0.9936301 \\
5 & 0.000443 & 0.0008376 & 0.0015875 & 0.0035019 & 0.9936301 \\
\hline 10 & & & & &
\end{tabular}

Table A2. Asia-Pacific variance decomposition.

\begin{tabular}{cccccc}
\hline \multirow{2}{*}{$\begin{array}{c}\text { Forecast } \\
\text { Horizon }\end{array}$} & A_dlngdp & A_dlngvcs & A_dlnrec & A_dlnco 2 & A_dlnlabor \\
\cline { 2 - 6 } A_dlngdp & & & 0 & 0 & 0 \\
1 & 1 & 0 & 0 & 0.0165631 & 0.0065297 \\
5 & 0.9685149 & 0.005721 & 0.0026714 & 0.0065316 \\
10 & 0.9685128 & 0.005721 & 0.0026715 & 0.0165631 & 0.0065316 \\
A_dlngvcs & & & & & \\
1 & 0.0009344 & 0.9990656 & 0 & 0 & 0 \\
5 & 0.0055822 & 0.9917179 & 0.0002837 & 0.0013485 & 0.0010677 \\
10 & 0.0055822 & 0.9917179 & 0.0002837 & 0.0013486 & 0.0010677 \\
A_dlnrec & & & & & \\
1 & 0.0159327 & 0.0076805 & 0.9763867 & 0 & 0 \\
5 & 0.0294922 & 0.0264432 & 0.9259253 & 0.0034593 & 0.0146801 \\
10 & 0.0294925 & 0.0264431 & 0.9259233 & 0.0034593 & 0.0146817 \\
A_dlnco 2 & & & & & \\
1 & 0.0098183 & 0.0005127 & 0.0324005 & 0.9572686 & 0 \\
5 & 0.0098265 & 0.0026184 & 0.0318704 & 0.95025 & 0.0054347 \\
10 & 0.0098265 & 0.0026184 & 0.0318704 & 0.95025 & 0.0054347 \\
A_dlnlabor & & & & & \\
1 & 0.0159275 & 0.0060485 & 0.0007268 & 0.0000284 & 0.9772688 \\
5 & 0.0993128 & 0.0071406 & 0.0015168 & 0.0039228 & 0.8881068 \\
10 & 0.0993129 & 0.0071406 & 0.0015169 & 0.0039229 & 0.8881066 \\
\hline
\end{tabular}


Table A3. Caribbean-Latin America variance decomposition.

\begin{tabular}{cccccc}
\hline \multirow{2}{*}{$\begin{array}{c}\text { Forecast } \\
\text { Horizon }\end{array}$} & C_dlngdp & C_dlngvcs & C_dlnrec & C_dlnco 2 & C_dlnlabor \\
\cline { 2 - 6 } C_dlngdp & & & & 0 & \\
1 & 1 & 0 & 0 & 0.0058516 & 0.0155626 \\
5 & 0.9756536 & 0.0013499 & 0.0015821 & 0.00155626 \\
10 & 0.9756536 & 0.0013499 & 0.0015821 & 0.0058516 & 0.0155626 \\
C_dlngvcs & & & & & \\
1 & 0.015681 & 0.984319 & 0 & 0 & 0 \\
5 & 0.0186041 & 0.9775121 & 0.0009434 & 0.0025021 & 0.0004382 \\
10 & 0.0186041 & 0.9775121 & 0.0009434 & 0.0025022 & 0.0004383 \\
C_dlnrec & & & & & \\
1 & 0.0035186 & 0.0022672 & 0.9942143 & 0 & 0 \\
5 & 0.0047287 & 0.0083537 & 0.9818271 & 0.0019437 & 0.0031469 \\
10 & 0.0047287 & 0.0083537 & 0.9818271 & 0.0019437 & 0.0031469 \\
C_dlnco 2 & & & & & \\
1 & 0.0094439 & 0.0119188 & 0.0614551 & 0.9171823 & 0 \\
5 & 0.0134228 & 0.0113824 & 0.0588137 & 0.8834816 & 0.0328995 \\
10 & 0.0134228 & 0.0113824 & 0.0588137 & 0.8834816 & 0.0328995 \\
C_dlnlabor & & & & & \\
1 & 0.0000293 & 0.0007297 & 0.0007281 & 0.0024042 & 0.9961088 \\
5 & 0.0027462 & 0.0008535 & 0.0008787 & 0.0104012 & 0.9851205 \\
10 & 0.0027462 & 0.0008535 & 0.0008787 & 0.0104012 & 0.9851205 \\
\hline
\end{tabular}

Table A4. MENA variance decomposition.

\begin{tabular}{cccccc}
\hline \multirow{2}{*}{$\begin{array}{c}\text { Forecast } \\
\text { Horizon }\end{array}$} & M_dlngdp & M_dlngvcs & M_dlnrec & M_dlnco 2 & M_dlnlabor \\
\cline { 2 - 6 } M_dlngdp & & & 0 & 0 & 0 \\
1 & 1 & 0 & 0 & 0.0572782 & 0.0045341 \\
5 & 0.9327897 & 0.0047878 & 0.0006104 & 0.0045363 \\
10 & 0.9327785 & 0.0047883 & 0.0006116 & 0.0572853 & 0.00 \\
M_dlngvcs & & & & & \\
1 & 0.0804942 & 0.9195058 & 0 & 0 & 0 \\
5 & 0.1397596 & 0.8098994 & 0.0065298 & 0.0072645 & 0.0365466 \\
10 & 0.1397675 & 0.8098409 & 0.0065295 & 0.0072955 & 0.0365665 \\
M_dlnrec & & & & & \\
1 & 0.000492 & 0.0324807 & 0.9670274 & 0 & 0 \\
5 & 0.0007078 & 0.0318093 & 0.9002398 & 0.0067105 & 0.0605325 \\
10 & 0.0007092 & 0.0318093 & 0.900238 & 0.0067106 & 0.0605329 \\
M_dlnco 2 & & & & & \\
1 & 0.0188852 & 0.000034 & 0.0025907 & 0.9784901 & 0 \\
5 & 0.0342636 & 0.0023953 & 0.0067691 & 0.8374305 & 0.1191416 \\
10 & 0.0342653 & 0.0023968 & 0.006769 & 0.8374217 & 0.1191472 \\
M_dlnlabor & & & & & \\
1 & $4.71 \mathrm{e}-06$ & 0.0124864 & 0.0337619 & 0.0111924 & 0.9425546 \\
5 & 0.0038516 & 0.0126314 & 0.0406818 & 0.0126392 & 0.9301959 \\
10 & 0.003854 & 0.0126313 & 0.0406818 & 0.0126393 & 0.9301935 \\
\hline
\end{tabular}


Table A5. Sub-Saharan Africa variance decomposition.

\begin{tabular}{cccccc}
\hline \multirow{2}{*}{$\begin{array}{c}\text { Forecast } \\
\text { Horizon }\end{array}$} & S_dlngdp & S_dlngvcs & S_dlnrec & S_dlnco $2^{2}$ & S_dlnlabor \\
\cline { 2 - 6 } S_dlngdp & & & & 0 & \\
1 & 1 & 0 & 0 & 0.0008216 & 0.005103 \\
5 & 0.9939538 & 0.0000101 & 0.0001115 & 0.0051092 \\
10 & 0.9939475 & 0.0000101 & 0.0001117 & 0.0008216 & 0.005 \\
S_dlngvcs & & & & & \\
1 & 0.0570274 & 0.9429726 & 0 & 0 & 0 \\
5 & 0.0493443 & 0.8210868 & 0.001686 & 0.011641 & 0.116242 \\
10 & 0.0493382 & 0.8209726 & 0.0016901 & 0.0116396 & 0.1163596 \\
S_dlnrec & & & & & \\
1 & 0.0009768 & 0.0100072 & 0.989016 & 0 & 0 \\
5 & 0.0040452 & 0.0097622 & 0.9534488 & 0.000163 & 0.0325808 \\
10 & 0.0040453 & 0.0097618 & 0.9534098 & 0.0001631 & 0.0326201 \\
S_dlnco 2 & & & & & \\
1 & 0.0136769 & 0.0174686 & 0.1555864 & 0.8132681 & 0 \\
5 & 0.0142864 & 0.016486 & 0.1478383 & 0.7712708 & 0.0501184 \\
10 & 0.0142858 & 0.016485 & 0.1478309 & 0.771222 & 0.0501763 \\
S_dlnlabor & & & & & \\
1 & 0.0053845 & 0.0001842 & 0.0017887 & 0.0036807 & 0.9889619 \\
5 & 0.0050332 & 0.0001584 & 0.0081326 & 0.0032284 & 0.9834474 \\
10 & 0.0050332 & 0.0001584 & 0.0081391 & 0.0032279 & 0.9834414 \\
\hline
\end{tabular}

\section{Appendix C}

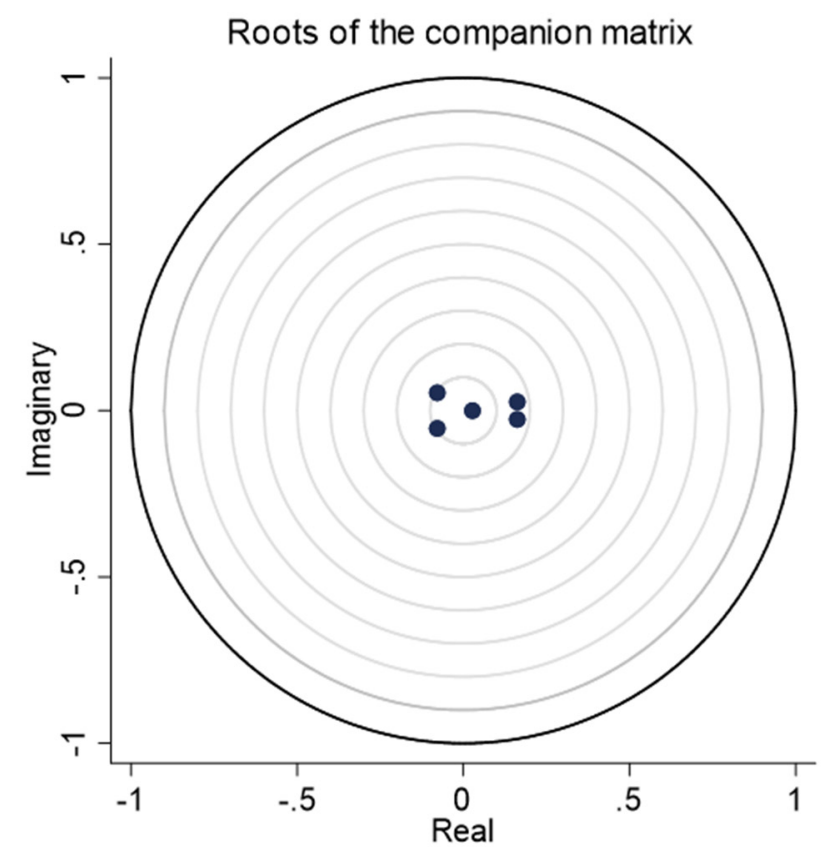

Figure A1. Global stability graph. 


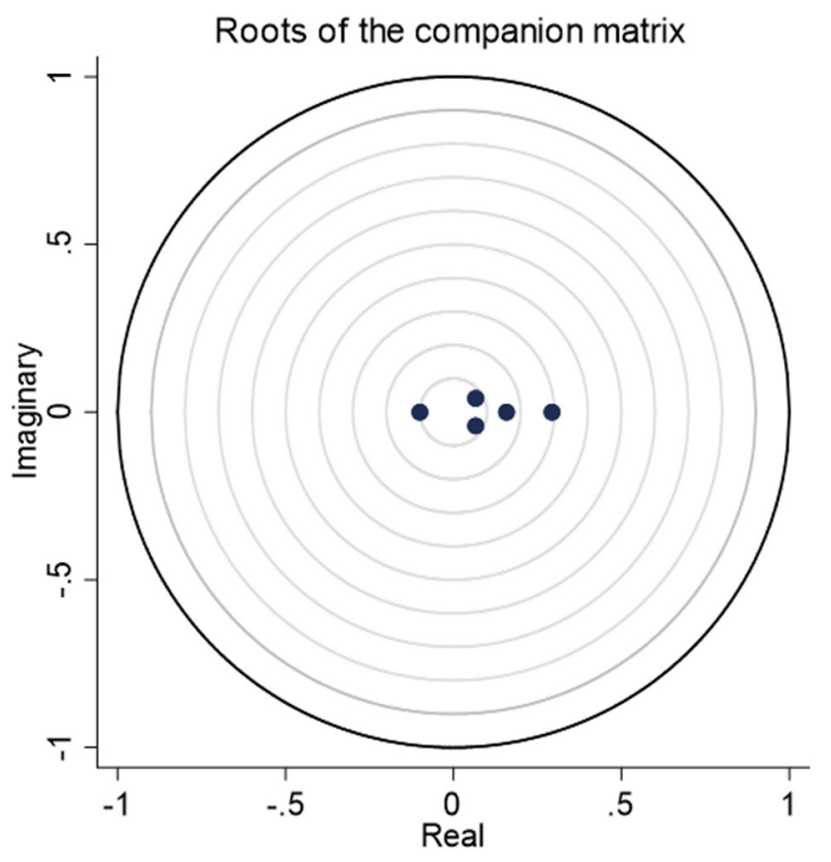

Figure A2. Asia-Pacific stability graph.

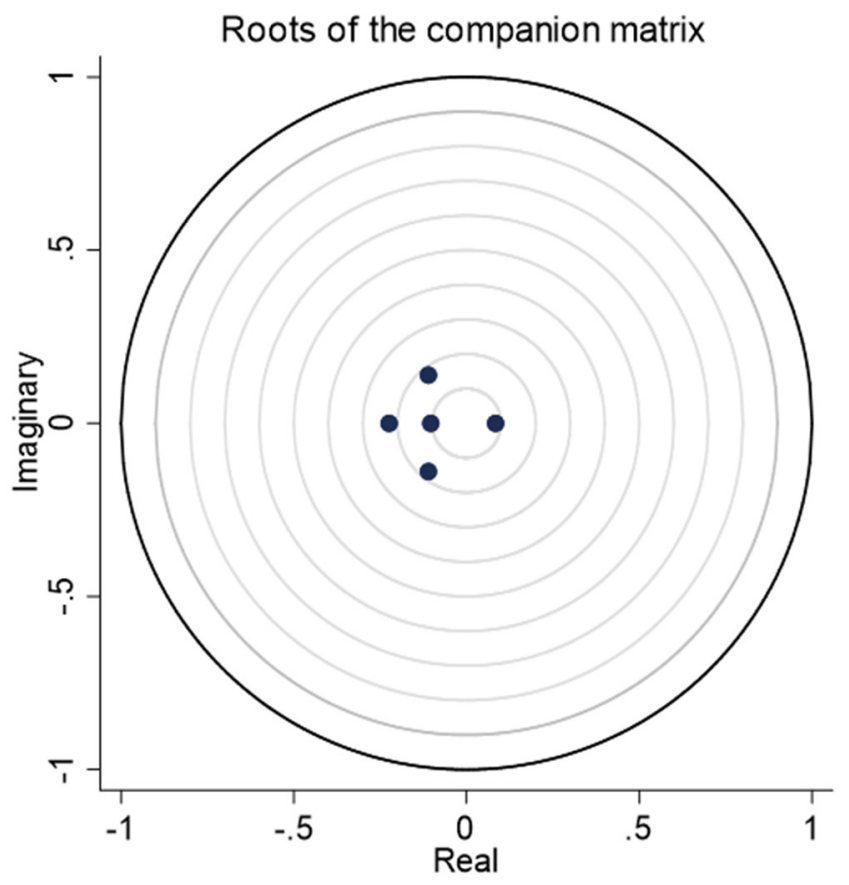

Figure A3. Caribbean-Latin America stability graph. 


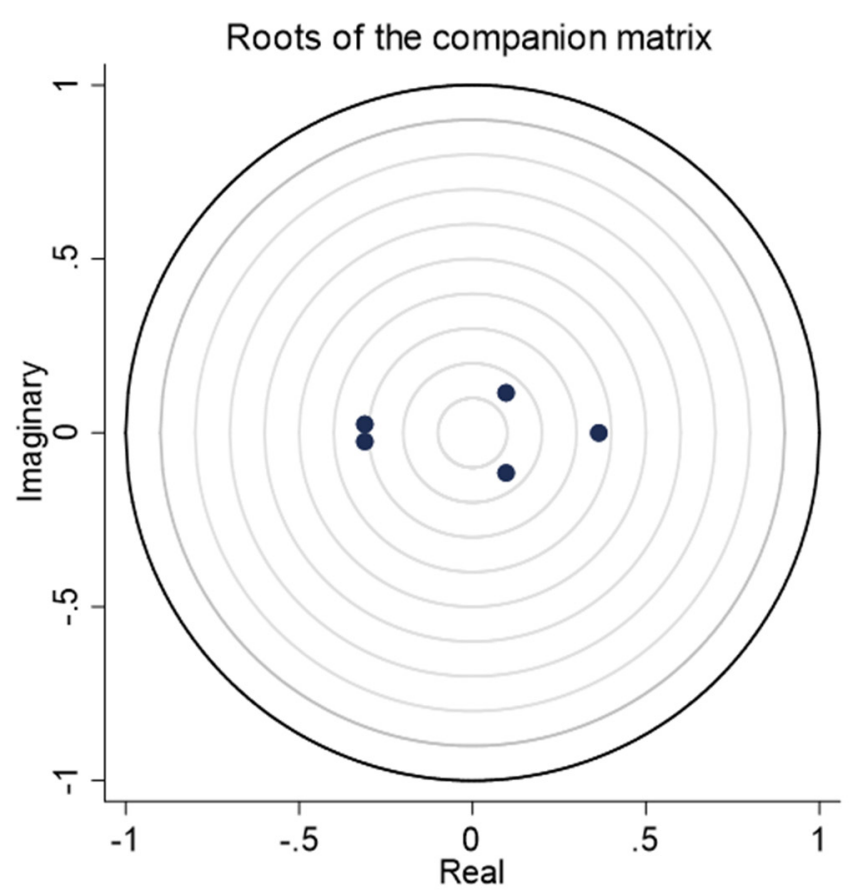

Figure A4. MENA stability graph.

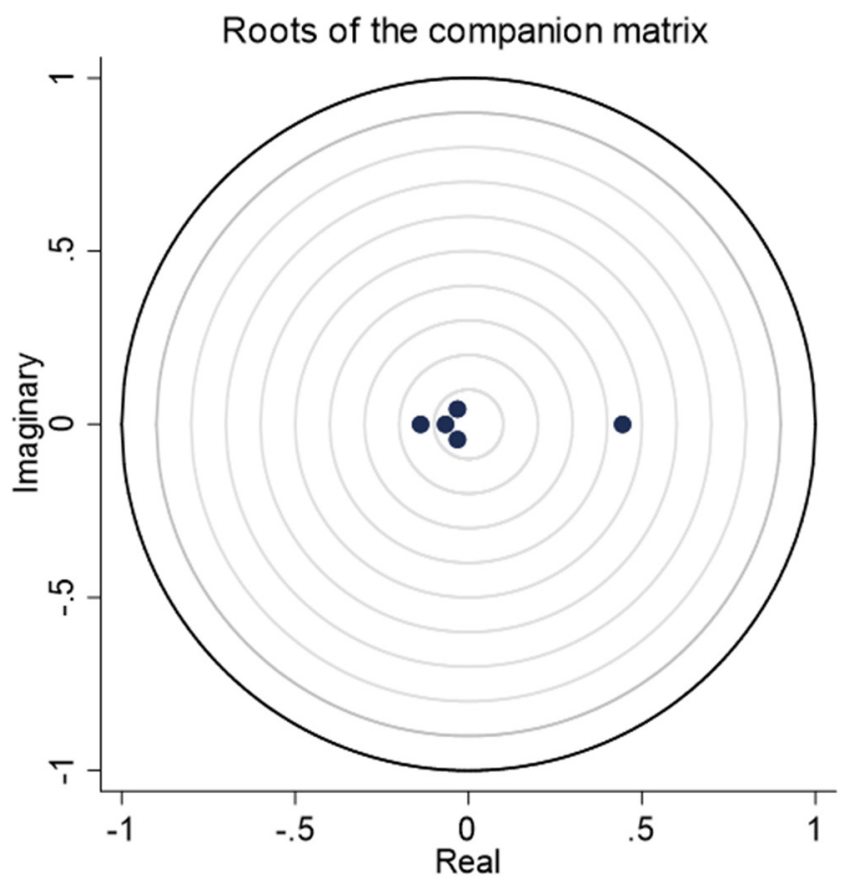

Figure A5. Sub-Saharan Africa stability graph.

\section{References}

1. Yuan, X.C.; Wei, Y.M.; Wang, B.; Mi, Z. Risk management of extreme events under climate change. J. Clean. Prod. 2017, 166, 1169-1174. [CrossRef]

2. Mohammadi, A.; Cowie, A.L.; Anh Mai, T.L.; Brandão, M.; Anaya de la Rosa, R.; Kristiansen, P.; Joseph, S. Climate-change and health effects of using rice husk for biochar-compost: Comparing three pyrolysis systems. J. Clean. Prod. 2017, 162, 260-272. [CrossRef]

3. Deschenes, O. Temperature, human health, and adaptation: A review of the empirical literature. Energy Econ. 2014, 46, 606-619. [CrossRef] 
4. Charfeddine, L.; Kahia, M. Impact of renewable energy consumption and financial development on $\mathrm{CO}_{2}$ emissions and economic growth in the MENA region: A panel vector autoregressive (PVAR) analysis. Renew. Energy 2019, 139, 198-213. [CrossRef]

5. Pei, J.; Meng, B.; Wang, F.; Xue, J.; Zhao, Z. Production sharing, demand spillovers and $\mathrm{CO}_{2}$ Emissions: The case of Chinese regions in global value chains. Singap. Econ. Rev. 2018, 63, 275-293. [CrossRef]

6. Liu, H.; Zong, Z.; Hynes, K.; De Bruyne, K. Can China reduce the carbon emissions of its manufacturing exports by moving up the global value chain? Res. Int. Bus. Financ. 2019, 51, 101101. [CrossRef]

7. Thorlakson, T.; De Zegher, J.F.; Lambin, E.F. Companies' contribution to sustainability through global supply chains. Proc. Natl. Acad. Sci. USA 2018, 115, 2072-2077. [CrossRef]

8. Pérez, K.; González-Araya, M.C.; Iriarte, A. Energy and GHG emission efficiency in the Chilean manufacturing industry: Sectoral and regional analysis by DEA and Malmquist indexes. Energy Econ. 2017, 66, 290-302. [CrossRef]

9. Mundaca, G. How much can $\mathrm{CO}_{2}$ emissions be reduced if fossil fuel subsidies are removed? Energy Econ. 2017, 64, 91-104. [CrossRef]

10. Lin, B.; Zhu, J. Energy and carbon intensity in China during the urbanization and industrialization process: A panel VAR approach. J. Clean. Prod. 2020, 168, 780-790. [CrossRef]

11. Wang, C.; Wang, F.; Zhang, X.; Yang, Y.; Su, Y.; Ye, Y.; Zhang, H. Examining the driving factors of energy related carbon emissions using the extended STIRPAT model based on IPAT identity in Xinjiang. Renew. Sustain. Energy Rev. 2017, 67, 51-61. [CrossRef]

12. Shuai, C.; Shen, L.; Jiao, L.; Wu, Y.; Tan, Y. Identifying key impact factors on carbon emission: Evidences from panel and time-series data of 125 countries from 1990 to 2011. Appl. Energy 2017, 187, 310-325. [CrossRef]

13. Ozturk, I. Measuring the impact of alternative and nuclear energy consumption, carbon dioxide emissions and oil rents on specific growth factors in the panel of Latin American countries. Prog. Nucl. Energy 2017, 100, 71-81. [CrossRef]

14. Foxon, T.; Pearson, P. Overcoming barriers to innovation and diffusion of cleaner technologies: Some features of a sustainable innovation policy regime. J. Clean. Prod. 2008, 1, 148-161. [CrossRef]

15. Gosens, J.; Lu, Y. From lagging to leading? Technological innovation systems in emerging economies and the case of Chinese wind power. Energy Policy 2013, 60, 234-250. [CrossRef]

16. Pietrobelli, C.; Bank, I.D.; Dc, W.; Rabellotti, R.; Orientale, P. Global value chains meet innovation systems: Are there learning opportunities for developing countries? World Dev. 2011, 39, 1261-1269. [CrossRef]

17. Ferrarini, B.; De Vries, G.J. What Accounts for the Growth of Carbon Dioxide Emissions in Advanced and Emerging Economies? The Role of Consumption, Technology, and Global Supply Chain Trade. Asian Development Bank Economics Working Paper Series. 2015, 458, 1-27. [CrossRef]

18. Achabou, M.A.; Dekhili, S.; Hamdoun, M. Environmental Upgrading of Developing Country Firms in Global Value Chains. Bus. Strategy Environ. 2017, 26, 224-238. [CrossRef]

19. Khattak, A.; Stringer, C.; Benson-Rea, M.; Haworth, N. Environmental upgrading of apparel firms in global value chains: Evidence from Sri Lanka. Compet. Chang. 2015, 19, 317-335. [CrossRef]

20. Örgün, B.O. GVCs participation as development strategy. Procedia-Soc. Behav. Sci. 2014, 150, 1287-1296. [CrossRef]

21. Song, M.; Wang, S. Participation in global value chain and green technology progress: Evidence from big data of Chinese enterprises. Environ. Sci. Pollut. Res. 2017, 24, 1648-1661. [CrossRef] [PubMed]

22. Hauknes, J.; Knell, M. Embodied knowledge and sectoral linkages: An input-output approach to the interaction of high- and low-tech industries. Res. Policy 2009, 38, 459-469. [CrossRef]

23. Bi, K.; Huang, P.; Ye, H. Risk identification, evaluation and response of low-carbon technological innovation under the global value chain: A case of the Chinese manufacturing industry. Technol. Forecast. Soc. Chang. 2015, 100, 238-248. [CrossRef]

24. Jiang, X.; Liu, Y. Global value chain, trade and carbon: Case of information and communication technology manufacturing sector. Energy Sustain. Dev. 2015, 25, 1-7. [CrossRef]

25. Javorcik, B.S. Does foreign direct investment increase the productivity of domestic firms? In search of spillovers through backward linkages. Am. Econ. Rev. 2003, 94, 605-627. [CrossRef]

26. Ramanathan, U.; Bentley, Y.; Pang, G. The role of collaboration in the UK green supply chains: An exploratory study of the perspectives of suppliers, logistics and retailers. J. Clean. Prod. 2014, 70, 231-241. [CrossRef] 
27. De Marchi, V.; Di Maria, E.; Ponte, S. The greening of global value chains: Insights from the furniture industry. Compet. Chang. 2013, 17, 299-318. [CrossRef]

28. De Marchi, V.; Giuliani, E.; Rabellotti, R. Do global value chains offer developing countries learning and innovation opportunities? Eur. J. Dev. Res. 2018, 30, 389-407. [CrossRef]

29. Closs, D.J.; Speier, C.; Meacham, N. Sustainability to support end-to-end value chains: The role of supply chain management. J. Acad. Mark. Sci. 2011, 39, 101-116. [CrossRef]

30. Manning, S.; Boons, F.; Von Hagen, O.; Reinecke, J. National contexts matter: The co-evolution of sustainability standards in global value chains. Ecol. Econ. 2012, 83, 197-209. [CrossRef]

31. Khattak, A.; Stringer, C. Environmental Upgrading in Pakistan's Sporting Goods Industry in Global Value Chains: A Question of Progress? Bus. Econ. Rev. 2017, 9, 43-64. [CrossRef]

32. Kumar, A.; Jain, V.; Kumar, S. A comprehensive environment friendly approach for supplier selection. Omega 2014, 42, 109-123. [CrossRef]

33. Cashore, B.; Auld, G.; Bernstein, S.; Mcdermott, C. Can Non-state Governance 'Ratchet Up' Global Environmental Standards? Lessons from the Forest Sector. Rev. Eur. Community Int. Environ. Law 2007, 16, 158-172. [CrossRef]

34. Geibler, J. Von Market-based governance for sustainability in value chains: Conditions for successful standard setting in the palm oil sector. J. Clean. Prod. 2013, 56, 39-53. [CrossRef]

35. Guide, V.D.R.; Jayaraman, V.; Linton, J.D. Building contingency planning for closed-loop supply chains with product recovery. J. Oper. Manag. 2003, 21, 259-279. [CrossRef]

36. Jiang, X.; Green, C. The Impact on Global Greenhouse Gas Emissions of Geographic Shifts in Global Supply Chains. Ecol. Econ. 2017, 139, 102-114. [CrossRef]

37. Liu, H.; Li, J.; Long, H.; Li, Z.; Le, C. Promoting energy and environmental efficiency within a positive feedback loop: Insights from global value chain. Energy Policy 2018, 121, 175-184. [CrossRef]

38. Elhedhli, S.; Merrick, R. Green supply chain network design to reduce carbon emissions. Transp. Res. Part D 2012, 17, 370-379. [CrossRef]

39. Bonilla, D.; Keller, H.; Schmiele, J. Climate policy and solutions for green supply chains: Europe's predicament. Supply Chain Manag. 2015, 20, 249-263. [CrossRef]

40. Coe, N.M. Review of International Political Economy Missing links: Logistics, governance and upgrading in a shifting global economy. Rev. Int. Political Econ. 2013, 37-41.

41. Memedovic, O. Fuelling the global value chains: What role for logistics capabilities? Lauri Ojala Jean-Paul Rodrigue Tapio Naula. Int. J. Technol. Learn. Innov. Dev. 2008, 1, 353-374. [CrossRef]

42. Poulsen, R.T.; Ponte, S.; Sornn-Friese, H. Environmental upgrading in global value chains: The potential and limitations of ports in the greening of maritime transport. Geoforum 2018, 89, 83-95. [CrossRef]

43. Kaltenegger, O.; Löschel, A.; Pothen, F. The effect of globalisation on energy footprints: Disentangling the links of global value chains. Energy Econ. 2017, 68, 148-168. [CrossRef]

44. Spaiser, V.; Scott, K.; Owen, A.; Holland, R. Consumption-based accounting of CO2 emissions in the sustainable development Goals Agenda. Int. J. Sustain. Dev. World Ecol. 2019, 26, 282-289. [CrossRef]

45. Wang, S.; Zhao, Y.; Wiedmann, T. Carbon emissions embodied in China-Australia trade: A scenario analysis based on input-output analysis and panel regression models. J. Clean. Prod. 2019, 220, 721-731. [CrossRef]

46. Davis, S.J.; Caldeira, K. Consumption-based accounting of $\mathrm{CO}_{2}$ emissions. Proc. Natl. Acad. Sci. USA 2010, 107, 5687-5693. [CrossRef]

47. Gereffi, G. Commodity Chains and Global Capitalism; Korzeniewicz, M., Ed.; ABC-CLIO: London, UK, 1994.

48. Gereffi, G. Shifting governance structures in global commodity chains, with special reference to the Internet. Am. Behav. Sci. 2001, 44, 1616-1637. [CrossRef]

49. Hummels, D.; Ishii, J.; Yi, K.-M. The nature and growth of vertical specialization in world trade. J. Int. Econ. 2001, 54, 75-96. [CrossRef]

50. Daudin, G.; Rifflart, C.; Schweisguth, D. Who Produces for Whom in the World Economy? Can. J. Econ./Revue Canadienne d'Économique 2011, 44, 1403-1437. [CrossRef]

51. Johnson, R.C.; Noguera, G. Accounting for intermediates: Production sharing and trade in value added. J. Int. Econ. 2012, 86, 224-236. [CrossRef]

52. Koopman, R.; Wang, Z. The value-added structure of gross exports and global production network. In Proceedings of the Final WIOD Conference Causes and Consequences of Globalization, Groningen, The Netherlands, 24-26 April 2012; pp. 24-26. 
53. Koopman, R.; Powers, W.; Wang, Z.; Wei, S. Give credit where credit is due: Tracing value added in global production chains. NBER Work. Pap. Ser. 2010. [CrossRef]

54. Koopman, R.; Wang, Z.; Wei, S.-J. Tracing value-added and double counting in gross exports. Am. Econ. Rev. 2014, 104, 459-494. [CrossRef]

55. Tan, K.G.; Nguyen, L.; Duong, T.; Chuah, H.Y. Impact of exchange rates on ASEAN's trade in the era of global value chains: An empirical assessment. J. Int. Trade Econ. Dev. 2019, 28, 1-29. [CrossRef]

56. Amendolagine, V.; Presbitero, A.F.; Rabellotti, R.; Sanfilippo, M. Local sourcing in developing countries: The role of foreign direct investments and global value chains. World Dev. 2019, 113, 73-88. [CrossRef]

57. Balié, J.; Davide Del, P.; Magrini, E.; Montalbano, P.; Nenc, S. Food and agriculture global value chains: new evidence from Sub-Saharan Africa. In Governance for Structural Transformation in Africa; Palgrave Macmillan: London, UK, 2019; pp. 251-276. [CrossRef]

58. Del Prete, D.; Giovannetti, G.; Marvasi, E. Global value chains: New evidence for North Africa. Int. Econ. 2018, 153, 42-54. [CrossRef]

59. Chiou, T.; Kai, H.; Lettice, F.; Ho, S. The influence of greening the suppliers and green innovation on environmental performance and competitive advantage in Taiwan. Transp. Res. Part E 2011, 47, 822-836. [CrossRef]

60. Pathikonda, V.; Farole, T. The capabilities driving participation in global value chains. J. Int. Commer. Econ. Policy 2017, 8, 1750006. [CrossRef]

61. Meng, B.; Glen, P.; Meng, B.; Peters, G.P.; Wang, Z. Tracing greenhouse gas emissions in global value chains. Stanf. Cent. Int. Dev. Wording Pap. 2015, 525, 1-97.

62. Salim, R.A.; Rafiq, S. Why do some emerging economies proactively accelerate the adoption of renewable energy? Energy Econ. 2012, 34, 1051-1057. [CrossRef]

63. Liu, X.; Zhang, S.; Bae, J. The impact of renewable energy and agriculture on carbon dioxide emissions: Investigating the environmental Kuznets curve in four selected ASEAN countries. J. Clean. Prod. 2017, 164, 1239-1247. [CrossRef]

64. Jebli, M.B.; Youssef, S.B.; Ozturk, I. Testing environmental Kuznets curve hypothesis: The role of renewable and non-renewable energy consumption and trade in OECD countries. Ecol. Indic. 2016, 60, 824-831. [CrossRef]

65. Dogan, E.; Seker, F. Determinants of $\mathrm{CO}_{2}$ emissions in the European Union: The role of renewable and non-renewable energy. Renew. Energy 2016, 94, 429-439. [CrossRef]

66. Dong, K.; Sun, R.; Hochman, G. Do natural gas and renewable energy consumption lead to less $\mathrm{CO}_{2}$ emission? Empirical evidence from a panel of BRICS countries. Energy 2017, 141, 1466-1478. [CrossRef]

67. Dong, K.; Sun, R.; Li, H.; Liao, H. Does natural gas consumption mitigate $\mathrm{CO}_{2}$ emissions: Testing the environmental Kuznets curve hypothesis for 14 Asia-Pacific countries. Renew. Sustain. Energy Rev. 2018, 94, 419-429. [CrossRef]

68. Al-Mulali, U.; Ozturk, I. The investigation of environmental Kuznets curve hypothesis in the advanced economies: The role of energy prices. Renew. Sustain. Energy Rev. 2016, 54, 1622-1631. [CrossRef]

69. Balsalobre-Lorente, D.; Shahbaz, M.; Roubaud, D.; Farhani, S. How economic growth, renewable electricity and natural resources contribute to $\mathrm{CO}_{2}$ emissions? Energy Policy 2018, 113, 356-367. [CrossRef]

70. Bölük, G.; Mert, M. Fossil \& renewable energy consumption, GHGs (greenhouse gases) and economic growth: Evidence from a panel of EU (European Union) countries. Energy 2014, 74, 439-446.

71. Zoundi, Z. $\mathrm{CO}_{2}$ emissions, renewable energy and the Environmental Kuznets Curve, a panel cointegration approach. Renew. Sustain. Energy Rev. 2017, 72, 1067-1075. [CrossRef]

72. Bhattacharya, M.; Awaworyi, S.; Reddy, S. The dynamic impact of renewable energy and institutions on economic output and $\mathrm{CO}_{2}$ emissions across regions. Renew. Energy 2017, 111, 157-167. [CrossRef]

73. Menyah, K.; Wolde-Rufael, Y. CO2 emissions, nuclear energy, renewable energy and economic growth in the US. Energy Policy 2010, 38, 2911-2915. [CrossRef]

74. Pata, U.K. Renewable energy consumption, urbanization, financial development, income and $\mathrm{CO}_{2}$ emissions in Turkey: Testing EKC hypothesis with structural breaks. J. Clean. Prod. 2018, 187, 770-779. [CrossRef]

75. Dong, K.; Sun, R.; Hochman, G.; Zeng, X.; Li, H.; Jiang, H. Impact of natural gas consumption on $\mathrm{CO}_{2}$ emissions: Panel data evidence from China's provinces. J. Clean. Prod. 2017, 162, 400-410. [CrossRef]

76. Ben Jebli, M.; Ben Youssef, S. The environmental Kuznets curve, economic growth, renewable and non-renewable energy, and trade in Tunisia. Renew. Sustain. Energy Rev. 2015, 47, 173-185. [CrossRef] 
77. Dong, K.; Sun, R.; Jiang, H.; Zeng, X. $\mathrm{CO}_{2}$ emissions, economic growth, and the environmental Kuznets curve in China: What roles can nuclear energy and renewable energy play? J. Clean. Prod. 2018, 196, 51-63. [CrossRef]

78. Sinha, A.; Shahbaz, M. Estimation of environmental Kuznets curve for $\mathrm{CO}_{2}$ emission: Role of renewable energy generation in India. Renew. Energy 2018, 119, 703-711. [CrossRef]

79. Love, I.; Zicchino, L. Financial development and dynamic investment behavior: Evidence from panel VAR. Q. Rev. Econ. Financ. 2006, 46, 190-210. [CrossRef]

80. Cai, X.; Che, X.; Zhu, B.; Zhao, J.; Xie, R. Will developing countries become pollution havens for developed countries? An empirical investigation in the Belt and Road. J. Clean. Prod. 2018, 198, 624-632. [CrossRef]

81. Balié, J.; Del Prete, D.; Magrini, E.; Montalbano, P.; Nenci, S. Does Trade Policy Impact Food and Agriculture Global Value Chain Participation of Sub-Saharan African Countries? Am. J. Agric. Econ. 2019, 101, 773-789. [CrossRef]

82. De Vries, G.J.; Ferrarini, B. What Accounts for the Growth of Carbon Dioxide Emissions in Advanced and Emerging Economies? The Role of Consumption, Technology and Global Supply Chain Participation. Ecol. Econ. 2017, 132, 213-223. [CrossRef]

83. Sun, C.; Li, Z.; Ma, T.; He, R. Carbon efficiency and international specialization position: Evidence from global value chain position index of manufacture. Energy Policy 2019, 128, 235-242. [CrossRef]

84. Hamilton, J.D. Time Series Analysis; Princeton university press: Princeton, NJ, USA, 1994.

85. Lütkepohl, H. New Introduction to Multiple Time Series Analysis; Springer Science \& Business Media: Berlin, Germany, 2005.

86. Abrigo, M.R.M.; Love, I. Estimation of panel vector autoregression in Stata. Stata J. 2016, 16, 778-804. [CrossRef]

87. Sims, C.A. Macroeconomics and Reality. Econom. J. Econom. Soc. 1980, 48, 1-48. [CrossRef]

(C) 2020 by the authors. Licensee MDPI, Basel, Switzerland. This article is an open access article distributed under the terms and conditions of the Creative Commons Attribution (CC BY) license (http://creativecommons.org/licenses/by/4.0/). 